\title{
4 \\ Friend and Foe: the Orient in Rome
}

\author{
Rolf Michael Schneider \\ (Ludwig-Maximilians University, Munich)
}

\begin{abstract}
Yes, and you've never been able to understand the suggestiveness of paradox and contradiction.

That's your problem. You live and breathe paradox and contradiction, but you can no more see the beauty of them than the fish can see the beauty of water.
\end{abstract}

Niels Bohr to Werner Heisenberg in Michael Frayn's play Copenhagen, premiered in May 1998

A fter the Persian Wars a powerful rhetoric surfaced in Classical Athens and became a constant factor in the political thinking of the day, the rhetoric of Orientalism. Since the pioneering but contentious study of Edward Said on Orientalism: Western Concepts of the Orient, first published in 1978 , this rhetoric has acquired both a new cultural importance and a new political significance. ${ }^{1}$ It is interesting to note, however, that little attention has been paid to the counter-phenomenon, the rhetoric of Occidentalism. ${ }^{2}$ According to Cicero the division of the world into Orient and Occident was legitimised by the gods. In his book De natura deorum (2.164-165), he uses the terms Oriens and Occidens as the only two metaphors with which to describe the division of the world. The author concludes that the gods care equally for all parts and all people of the world. From the territorial powers of the East and the West he names, however, only four, first Rome, then Athens, Sparta and Rhodes. Rome's claimed supremacy over the Orient as the eastern half of the world marks a cornerstone of Roman Orientalism. My interest in the visual rhetoric of Orientalism has sensitised my view of the extent to which the notions of friend and foe, Orient and Occident, imagery and ideology are coloured by the (opposite) readings of the present political situation, especially in the Near East. ${ }^{3}$ These notions are to be found everywhere in contemporary written and visual media. My aim in this paper is to show how, in my own field of Greek and Roman imagery, the image addresses and transforms these notions, and conversely how it is affected by them. In comparison to a text, an 
image provides different qualities with which it stimulates social communication. ${ }^{4}$ The most distinctive quality of the image is its unique power of suggestion. An image can both catch the viewer's attention in a fraction of a second and stamp itself on his mind forever. This power of the image is crucial for my argument. At its core is the issue of how and by whom Roman images of the Oriental were shaped and perceived, and how these images functioned within, and contributed to, the culture of imperial Rome.

However, before I can focus on imperial Rome I need to pose some questions concerning Orientalism today. How do we perceive and deal with the imagery of the Orient(al) in our visual culture? How is this modern imagery shaped, how does it function and what does it mean? These questions affect not only how we behave culturally, think politically and act ideologically, but also how we approach the civilisations and the imageries of the past.

The scope of positive readings of Orientalism in the nineteenth century is epitomized by the self-(re)presentation of the Bavarian prince Otto, King of Greece from 1832 to $1862 .^{5}$ A colourised lithograph, printed around 1835 by Gottlieb Bodmer after a model of Dietrich Monten, shows King Otto in what was supposed to be Greek national dress, which was itself a cultural invention strongly based on Orientalised clothes (Fig. 1). ${ }^{6}$ A number of other images depict King Otto in the same eastern fashion. ${ }^{7}$ Today, however, we are more and more confronted with and controlled by images of the Oriental as a suspicious stranger or an explicit enemy as shown on the title page of Time Magazine from $15^{\text {th }}$ December $2003 .{ }^{8}$ Despite their obvious disparity both images use the same iconographic strategy to distinguish the Oriental Other: both use clothing as a distinctive marker to refer to a specific cultural body. From antiquity to the present day dress codes have played a key role in visualizing the difference between West and East, friend and foe. ${ }^{9}$ The visual Orientalism of the day is based on complex agendas, not only on the economic and political interests of the Christian West but also on its unrivalled hold over the public media.

In today's visual media the Orient(al) is mostly present as an exotic Other, a stranger and foe, whereas the image of the Orient(al) as friend is almost always missing. Uri Avnery's book My Friend, the Enemy published in 1986 is a rare exception. This one-sidedness marks a strong prejudice on the part of the West, a prejudice which has also severely biased the view of Classical scholars on Greek and Roman portrayals of the Oriental. ${ }^{10}$ It also underlines how much the analysis, perception and evaluation of any image is based on cultural preconceptions. We should keep this in mind when approaching the imagery of the Orient(al) at Rome. 


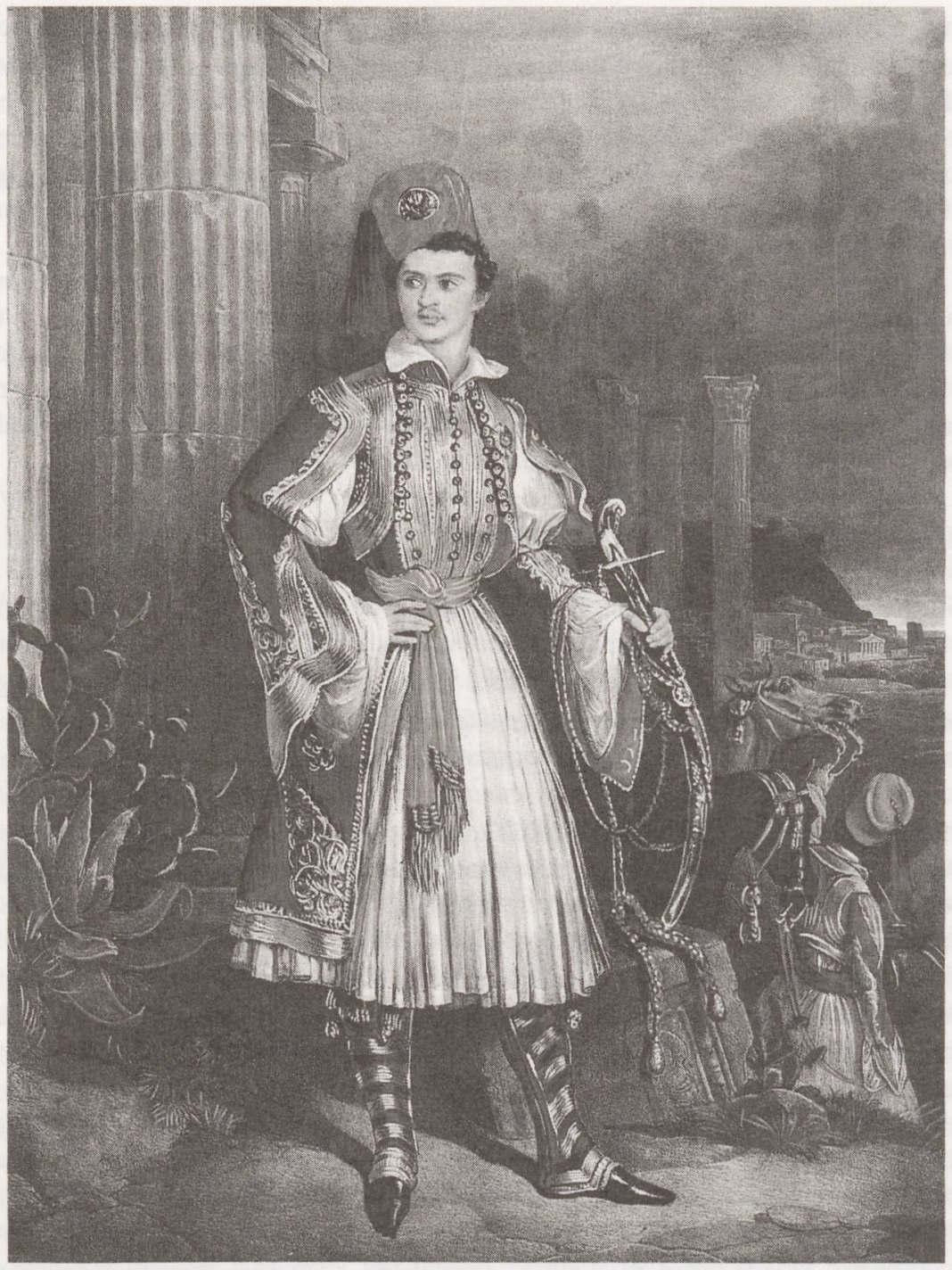

Fig. 1 Coloured lithograph of King Otto of Greece (H $56 \mathrm{~cm}, W 42$ cm). Printed in Munich c. 1835 by Gottlieb Bodmer after a model of Dietrich Monten. Ottobrunn (nr. Munich), König-Otto-von-Griechenland-Museum. 
The culture of imperial Rome was fundamentally related to non-Roman cultures. Rome used victories over non-Romans to legitimise imperial power. Rome claimed to rule the world. Rome integrated a wide range of different civilisations and ethnicities. ${ }^{11}$ And Rome communicated with people beyond the orbis Romanus. ${ }^{12}$ An empire of this diversity could in the long term only survive if it offered discourses of cultural flexibility and symbols of cultural identity capable of being widely adopted. ${ }^{13}$ One way to shape cultural identity was to establish images of the cultural Other. A model case of the cultural Other was the visual representation of non-Romans, stereotyped images of peoples living outside the Roman empire. The majority of these images portrayed the Other in the form of two Romanised ethnic costumes, representing the peoples of the North and the East. Images of non-Romans were present in all visual media, every social context and throughout the principate. In Rome the cultural Other was an influential and ambiguous reflection of the self-representation of Rome, or in other words, in contrast to the contemporary non-Roman civilisations the image of the ethnic Other was an essential constituent of Rome's cultural identity. Depending on time, place and function the image of the cultural Other oscillated in Rome between interrelated concepts such as fascination and demarcation, acceptance and contempt, friend and foe. This diversity in Roman visual narratives, however, is rarely reflected in modern scholarship. ${ }^{14}$ In general, Roman depictions of non-Romans are still considered to be simply portrayals of the barbarian Other, of peoples who lack the cultural standards of Greece and Rome. This view is deeply rooted in the western tradition of Occidental superiority. It is founded on the assumption that there is a fundamental asymmetry in the relationship between the Classical civilisations of Greece and Rome and the barbarian cultures beyond. ${ }^{15}$ In my view, however, the Roman imagery of the Oriental points to the need for a more subtle understanding of the Roman discourse of the non-Roman Other.

My approach to this imagery follows three different points of view. I begin with those Roman portrayals which characterise the Oriental by his distinctive non-Roman features such as posture, dress, physiognomy and hairstyle. This applies especially to the ethnic images of the Parthians. I then turn to Roman portrayals showing the Oriental as a handsome youth distinguished not only by posture and dress but also by a beautiful face and long hair. As this stereotype was used to portray all figures from the East, mythical and historical alike, I focus especially on Parthians, Trojans and Persians. Finally, I read the results of my iconographical research within the social, historical and ideological framework of the time, highlighting the following questions. By whom, how and when were the images of the Oriental conceptualised and set up in Rome? How did the Roman public perceive and deal with this imagery? And how did all this contribute to the shaping of the identity of imperial Rome, and the ideology of Roman Orientalism? 


\section{The Parthian: the foe beyond the Roman world}

Official relations between Romans and Parthians started late, with a treaty of Roman amicitia in 96 BCE. ${ }^{16}$ This situation changed when the Roman general Marcus Licinius Crassus attacked the Parthians in the winter of 55/54 BCE without first declaring war. After the defeat of Crassus and the loss of his entire army in $53 \mathrm{BCE}$, Caesar propagated the ideology of revenge on the Parthians, but did not initiate war. ${ }^{17}$ In 20 BCE, by exerting diplomatic and military pressure on Parthia, Augustus succeeded in recovering well over 100 Roman standards and thousands of captive Romans. Although it had been achieved through diplomacy, the so-called settlement of the Parthian question was marked in the public media of Rome as Augustus' greatest victory, as the final legitimation of his new imperial rule. ${ }^{18}$ Portrayals throughout the Roman empire propagated the Parthian settlement as the ultimate triumph of the Roman West over the East, and as one of the greatest achievements of Augustan foreign policy. The Augustan poets even introduced a cosmic dimension to the settlement: they construed it as the political prerequisite for the beginning of the Golden Age "heralded" by Augustus in $17 \mathrm{BCE}^{19}$ Consequently, Parthia and later the Sasanian empire constituted the only other (enemy) superpower next to Rome, and was perceived as such. ${ }^{20}$

The first Roman images of the Parthian emerged in the aftermath of this widely adopted self-congratulation. ${ }^{21}$ The most famous example is the Prima Porta statue of Augustus named after its provenance just north of Rome in the villa of the emperor's wife Livia (Figs. 2-3). ${ }^{22}$ The statue can be dated around 17 BCE. The two main figures of the richly decorated cuirass are depicted in the centre: a Parthian is presenting to a military representative of Rome a (Roman) standard adorned with a legionary eagle and at least two (possibly three) phalerae. Surrounded by non-interacting figures of geographic, cosmic and divine nature, they are the only two standing and interacting figures. Both are, however, portrayed in significant asymmetry: on the left, and larger in size, we see the cuirassed representative of Rome from a side view, extending his right hand as if to demand or receive the standard; on the right, the Parthian, smaller in size and mainly viewed from the front, gazes up towards the eagle. ${ }^{23}$ This depiction is the most detailed portrayal of a Parthian in Roman art (Fig. 3). Originally he would have been even more emphasized as he would have been distinctively coloured. ${ }^{24}$ The head of the Parthian is characterized by irregular curly hair, held in place with a flat ribbon or a diadem, a non-Classical nose, pronounced cheekbones, a moustache and a long beard. He is dressed in long trousers, a belted V-neck tunic with long sleeves and soft shoes. He is shown armed with a bow kept in a combination quiver and bow case (gorytus), which was attached to a belt running over his left shoulder. ${ }^{25}$ 
Fig. 2 Statue of Augustus, wearing a cuirass (H 2.06 m). From the imperial villa of Livia at Prima Porta. Roman, c. 17 BCE. Rome, Musei Vaticani, Braccio Nuovo.
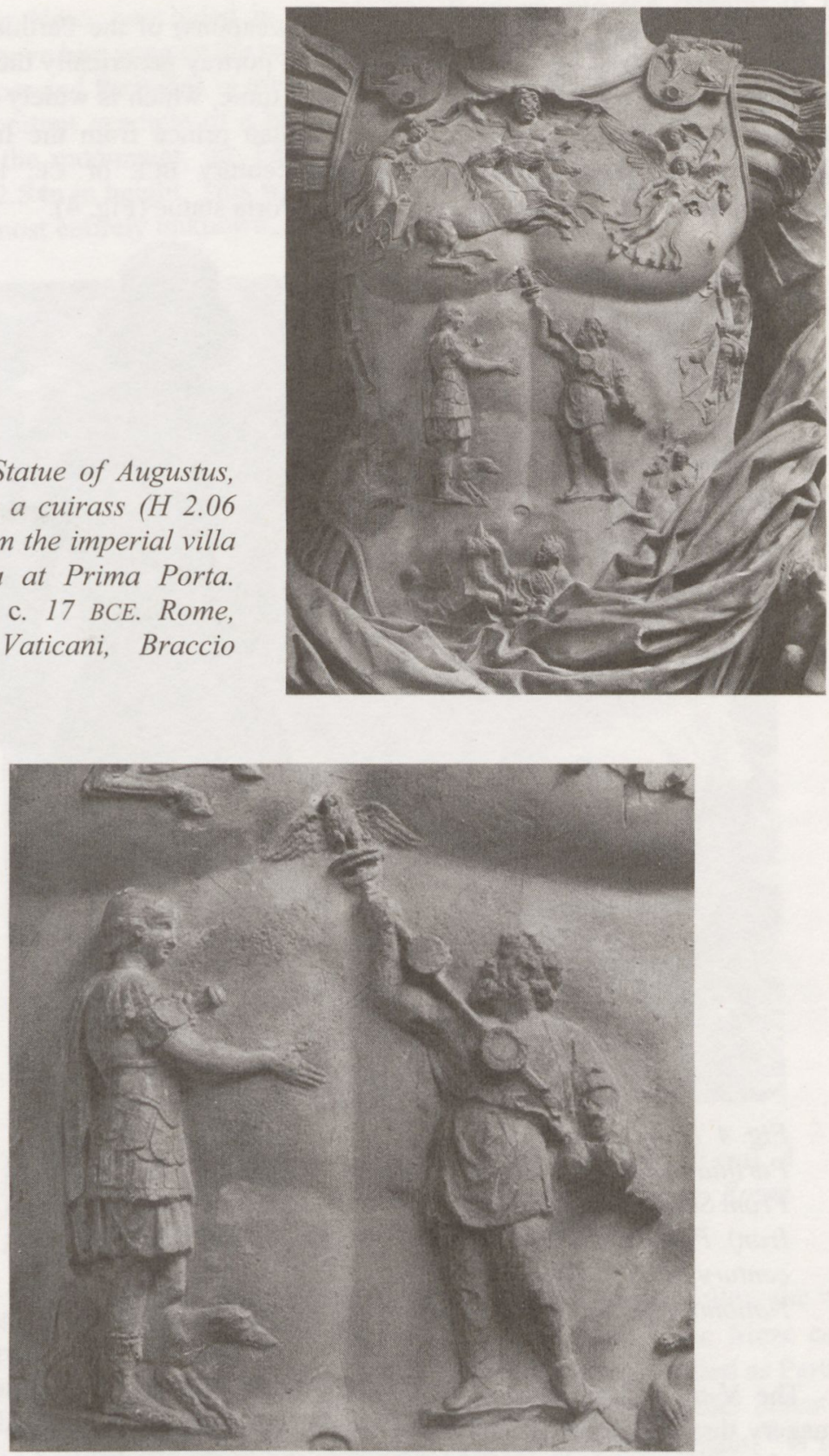

Fig. 3 Statue of Augustus. Detail of the Roman and the Parthian (see Fig. 2). 
The dress and physiognomy (but rarely the weapons) of the Parthian became stereotypes deployed by Roman workshops to portray generically the people of the East. Distinctively Parthian is the V-neck tunic, which is widely attested in Parthian art. ${ }^{26}$ The bronze statue of a Parthian prince from the Iranian site Shami, usually dated either to the first century BCE or CE, is roughly contemporary with the Parthian of the Prima Porta statue (Fig. 4). ${ }^{27}$

Fig. 4 Bronze statue of a Parthian prince (H $1.94 \mathrm{~m})$. From Shami (southwestern Iran). Parthian, c. first century BCE/CE. Tehran, National Museum of Iran.

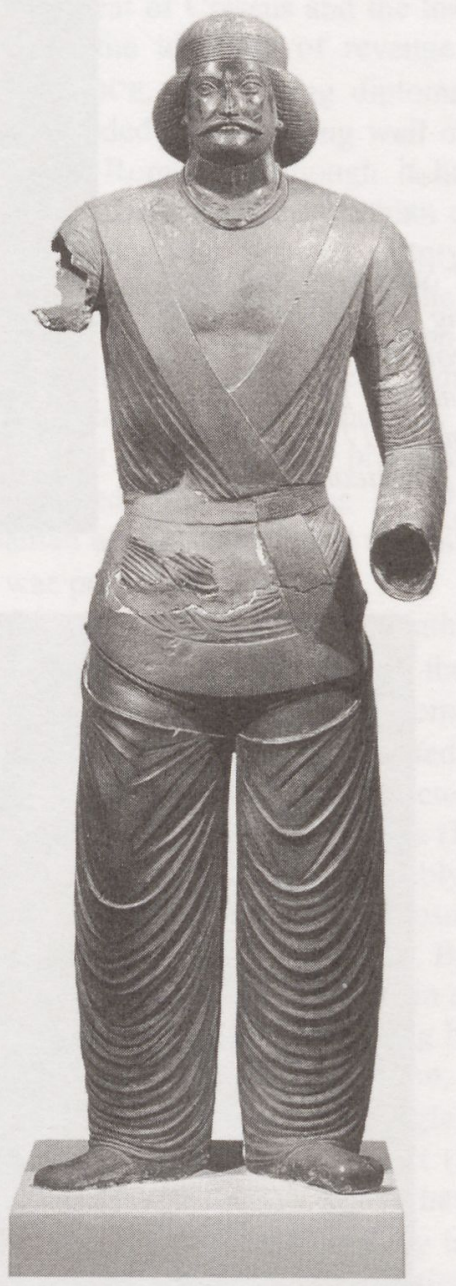

The V-neck tunic became a common feature of the Parthian in Roman imagery throughout the principate. Three images may be cited here to convey the ubiquitous reception of this garment in different media, contexts and periods. A fragment of a monumental marble relief in Rome shows the upper part of a fighting Parthian dressed in a V-neck tunic (Fig. 5). ${ }^{28}$ On thematic and stylistic grounds, Tonio Hölscher has dated the relief to the time of the Parthian 
war under Nero, concluded in CE 66. The Parthian and the remains of the shields above him suggest the reconstruction of a major battle between Romans in the upper and Parthians in the lower zone of the relief. It counts in fact as the most important example of a battle scene in early imperial Rome. As for the scale of the monument, the Parthian head implies that the figures measured roughly $2.5 \mathrm{~m}$ in height. This would point to an extremely large and important, albeit almost entirely unknown, imperial monument in Rome.

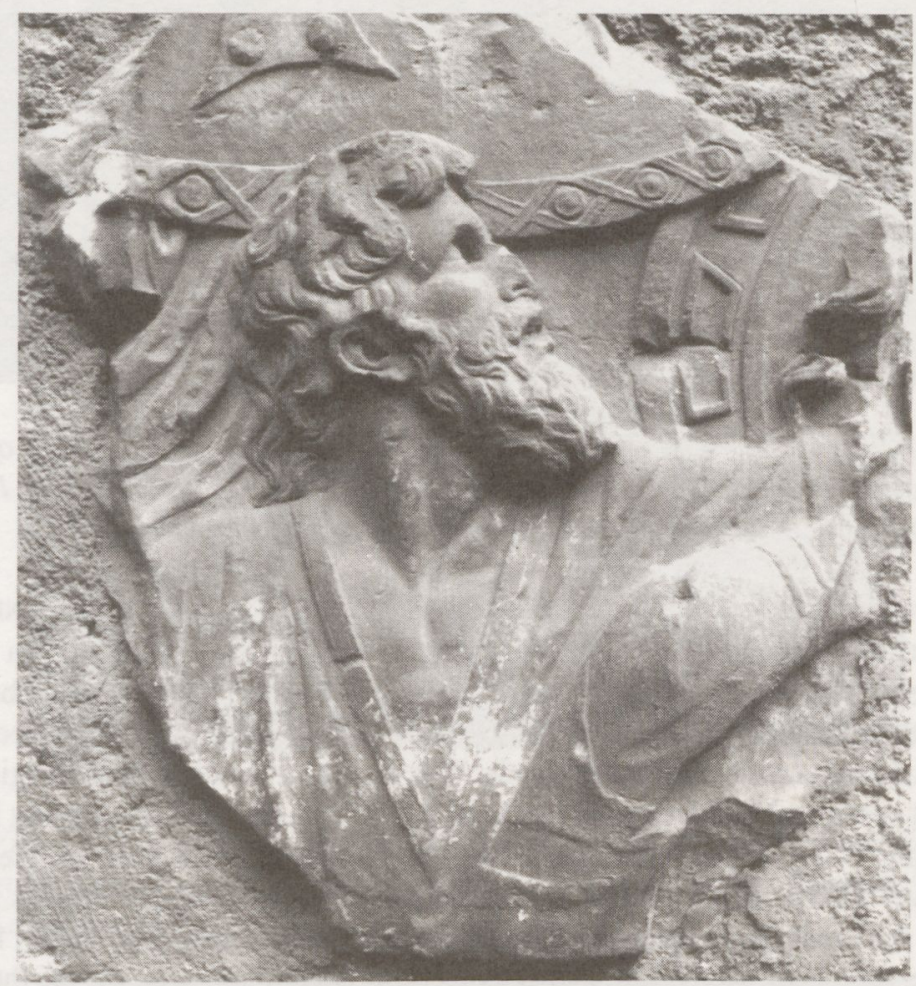

Fig. 5 Fragment of a monumental relief $(H 87 \mathrm{~cm}, W 59 \mathrm{~cm})$. A Parthian fights against Romans (not extant). From Rome. Roman, c. CE 60. Rome, Museo Nazionale Romano.

Fragments of a small ivory frieze found at Ephesus closely follow the visual standards set by the imperial imagery of Rome (Fig. 6). ${ }^{29}$ The frieze can be dated around CE 120. It shows bearded Orientals who are identified as Parthians again by their distinctive V-neck tunics. The Parthians are either defeated in battle or brought captive before a Roman general, probably Trajan. ${ }^{30}$ If this is correct, the frieze would relate to the Parthian war under Trajan. Unfortunately, we know nothing of either the function or the context of this frieze. 


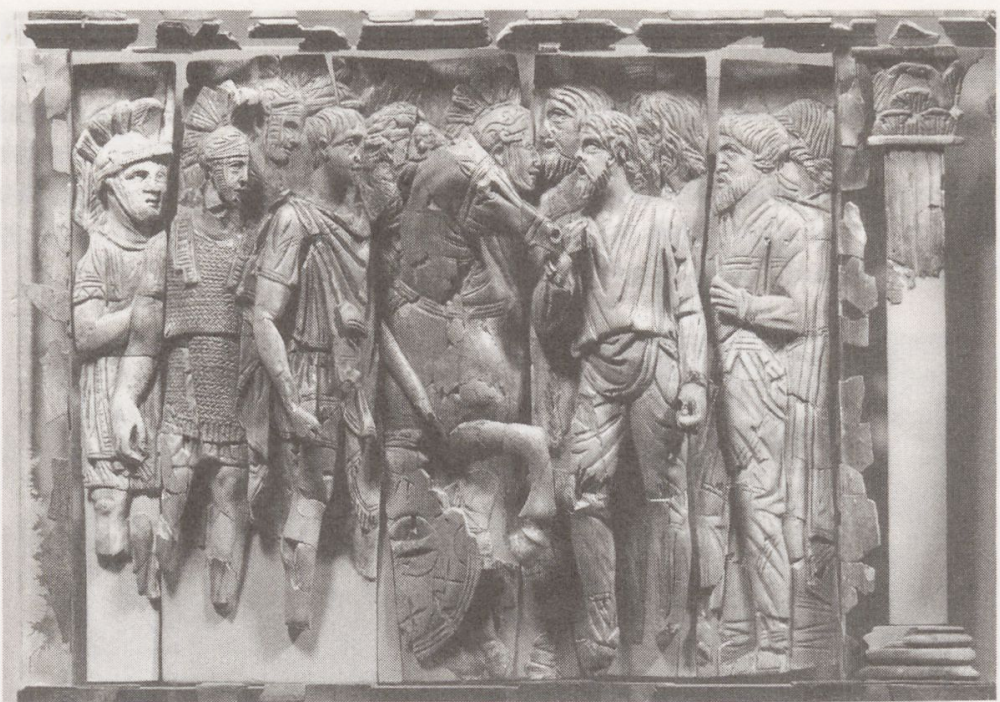

Fig. 6 Ivory frieze ( $H 20 \mathrm{~cm}, W 24 \mathrm{~cm}$ ). Captive Parthians in front of Trajan(?) and Roman soldiers. From Ephesus, Terrace House II (not found in situ). Roman, c. CE 120. Selçulk, Efes Müzesi.

A sculpted limestone fragment now in Trier offers a different context and a different iconography (Fig. 7). ${ }^{31}$ It may originally have adorned a grave monument of the later second century CE in Confluentes (Coblenz). A bearded man with beautiful curls stands almost frontally next to a pilaster decorated with abundant scrolls and exotic birds. The figure is wearing the Phrygian cap (without ear-flaps) and a trouser suit with a low V-neck, thus identifying him as a Parthian. ${ }^{32}$ The Oriental stranger is depicted in the role of a servant. He offers the viewer a tray, on which are set out several small rectangular objects. In my opinion the most likely interpretation of these objects is that they depict bars of gold, regarded in Rome as symbols of the legendary wealth of the East (Fig. 8). ${ }^{33}$ This image of a Parthian with his beautiful curls must have stimulated a more intricate reading than the images discussed so far. The Parthian who proffers gold bars is not necessarily portrayed as an enemy defeated in battle but as a fascinating stranger from the East serving a rich Roman(ised) master in the West. This image of a Parthian, from the edge of the Roman empire, seems to allude to a key ritual of Roman power, the staging of exotic spoils and foreign captives in the context of the triumphal procession. ${ }^{3}$

Roman portrayals of Parthians raise the question of what is known about actual contacts between the Parthians and the people of Rome. Under Augustus at least five Parthian legations are reported to have come to Rome. ${ }^{35}$ Eastern kings as well as hostages from the royal family of Parthia living with their Oriental entourages in Rome were regularly paraded in front of the Roman 


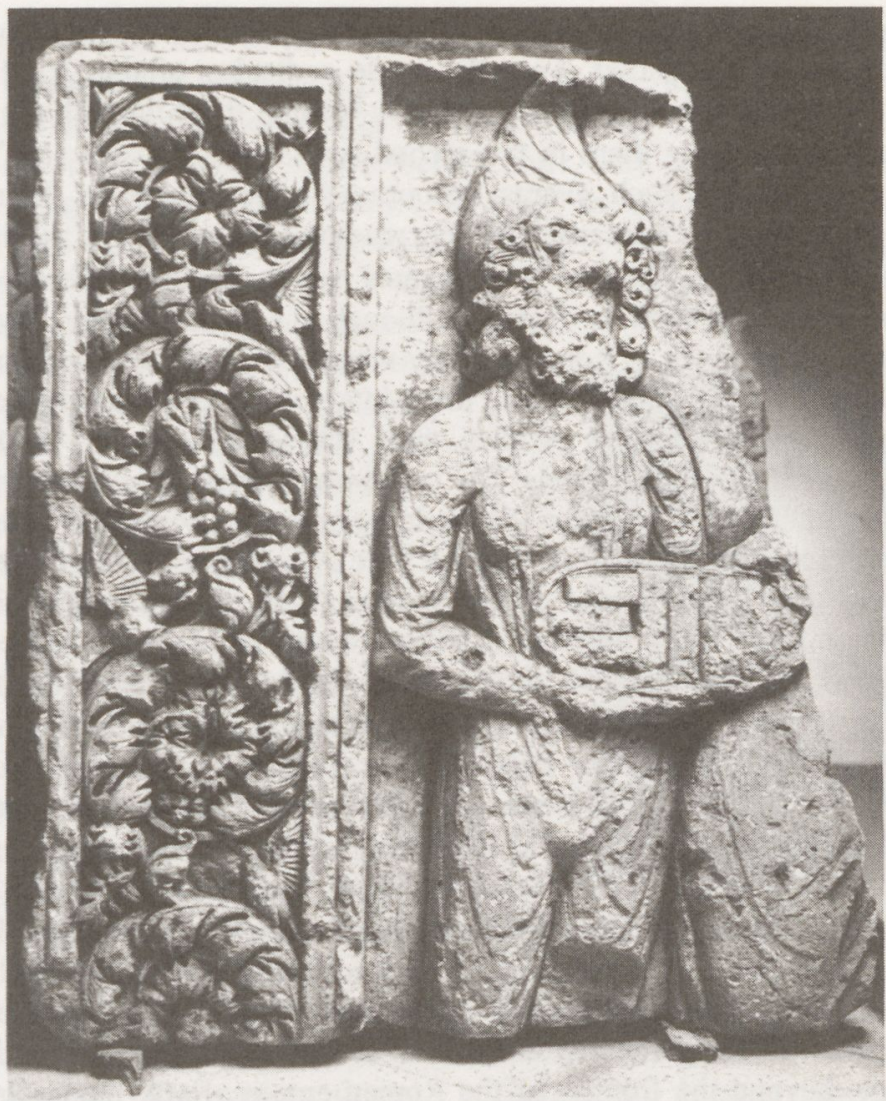

Fig. 7 Relief of local stone $(H 91 \mathrm{~cm}, W 77 \mathrm{~cm})$. A Parthian proffers gold bars. From Coblenz. Roman, c. CE 170. Trier, Rheinisches Landesmuseum.

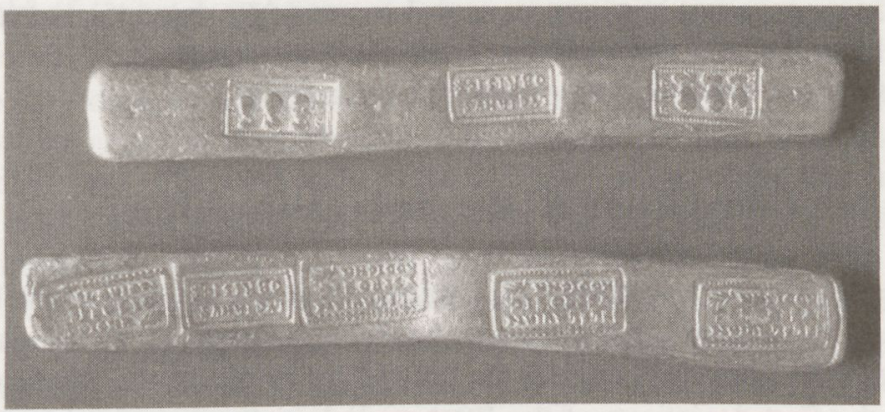

Fig. 8 Two bars of gold of Valentian I (524.2 gr. / $520 \mathrm{gr}$.). From Czófalva, Romania. Roman, CE 367-375. Vienna, Kunsthistorisches Museum. 
public. Suetonius reports on a visit by Augustus to the Circus Maximus: "On the day of one of the shows Augustus made a display of the first Parthian hostages that had ever been sent to Rome, by leading them through the middle of the arena and placing them in the second row above his own seat. ${ }^{, 36}$ It is more than likely that such events encouraged other forms of interactions between Romans and Parthians than the readings promoted by the imperial imagery and ideology of Rome. ${ }^{37}$ Such events reveal a further difference in the perception of the Parthian in Rome. Although the general appearance of a Parthian was well known at Rome, the city's workshops and their patrons were not interested in reproducing Parthian dress in authentic or ethnographic detail. Rather, when portraying the peoples from the Orient, Roman workshops followed established Greek models. The result was a conventionalised image of the Parthian adaptable to both the ideological needs of the imperial régime and the cultural preconceptions of the Roman élite. Accordingly, the image of the Parthian was used in public and domestic contexts to portray the Parthian in a variety of significant roles: defeated in battle, captive or as a desirable servant.

In general, we can say that little reliable information about Parthia was available in Rome. ${ }^{38}$ The Romans for the most part viewed the Parthians as once the Greek had viewed the Persians. The Achaemenid empire, Alexander the Great and the Seleucid kings provided the Romans with appropriate stereotypes with which they could imagine Parthia. Prominent among these were the lurid details of the Perso-Parthians' brutal despotism, legendary wealth, fantastic luxury, effeminate life-style and excessive sexuality. ${ }^{39}$ In these and further extremes the Parthian was Rome's most distinctive cultural Other. The Roman idea of the Other world of the Parthians acquired its fixed form after the return of the standards in 20 BCE. It was a world at a vast distance from Rome, beyond the frontier of the Roman empire. Early imperial writers such as Florus, Pompeius Trogus, Manilius and Tacitus represented the Other world of the Parthians as alius orbis and orbis alter. ${ }^{40}$ This orbis alter existed outside the orbis Romanus and did not impinge upon the Romans' view of their own supremacy. This Augustan concept of two opposing worlds reflects two apparently incongruent but interconnected issues of Roman imperial ideology, namely the asymmetry between Rome and the East, and Rome's interest in the (Parthian) Orient as her only true cultural counter-pole.

\section{The Oriental: the fascinating Other}

The most suggestive manifestation of the Roman perception of the Parthian Other world was the image of the handsome Oriental. This image was introduced into Roman art around the time of the return of the standards in 20 $\mathrm{BCE}$ and the first depictions of the Parthian. ${ }^{41}$ Initially developed in Classical Athens about 500 BCE, the image became the stereotype of the handsome Other of the East. ${ }^{42}$ Finally picked up by workshops in Rome it became the most 
successful ancient icon of the Orient(al) ${ }^{43}$ In contrast to the ethnic stereotype of the Parthian that we have already looked at, the handsome Oriental has a clean-shaven face framed by long coiffured hair and crowned by the Phrygian cap. He usually wears a double-belted tunic with long sleeves, a flowing mantle, long trousers and soft shoes. In short, he is distinguished by youthful beauty, rich dress and intensive colour (Figs. 9, 10, 12, 16, 17, 22-25). The historical - or rather mythical - identity of the Oriental is indicated by his attributes, clothing and/or context.

Such a stereotype made it possible to represent the people of the East as uniform and thus essentially the same: past and present people, ideal images of countries, and cosmic, mythical and divine figures, all could be denoted by the same image. The relation between the image of the handsome Oriental and the ethnic Parthian is shown by a white glass gem in Berlin, a specimen of a popular mass product of the Augustan period (Fig. 9). ${ }^{44}$ Two kneeling Orientals, cleanshaven and dressed in trousers and long-sleeved tunics, present Roman standards to Victory. The goddess is placed in the centre, on top of a celestial globe. The eastern dress, the Roman standards and Victory on top of the globe all define the

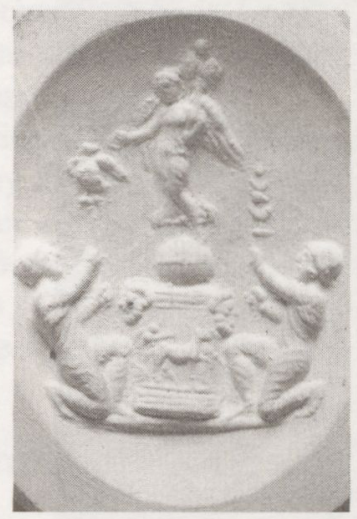

Fig. 9 Glass gem (H $3.5 \mathrm{~cm})$. Two kneeling Parthians present Roman standards to Victory. Roman, c. 20 BCE - CE 20. Berlin, Staatliche Museen zu Berlin, Antikensammlung. two Orientals as Parthians.

The ambiguity of the handsome Oriental is especially clear in Roman portrayals of Oriental cup bearers, which commonly served as table legs in Roman villas. ${ }^{45} \mathrm{~A}$ fine example is the marble figure found in the Casa del Camillo in Pompeii, and thus made before $79 \mathrm{CE}$ (Fig. 10). ${ }^{46}$ The figure portrays a luxury-class slave from the East: young, beautiful, clean-shaven and in Oriental dress. The wine ladle in his left hand denotes him as a cup-bearer who is depicted in the act not of serving but of waiting for orders. The popularity of the motif is suggested by a small marble figure from Palmyra (Fig. 11) ${ }^{47}$ In this case the cup bearer is portrayed not in stereotypical Oriental dress, but in the actual clothes of the Parthians living nearby in the East. In addition to the wine ladle in his left hand, he also holds a wine jug. The piece highlights both the widespread availability of the motif and its adaptability to local preferences. 


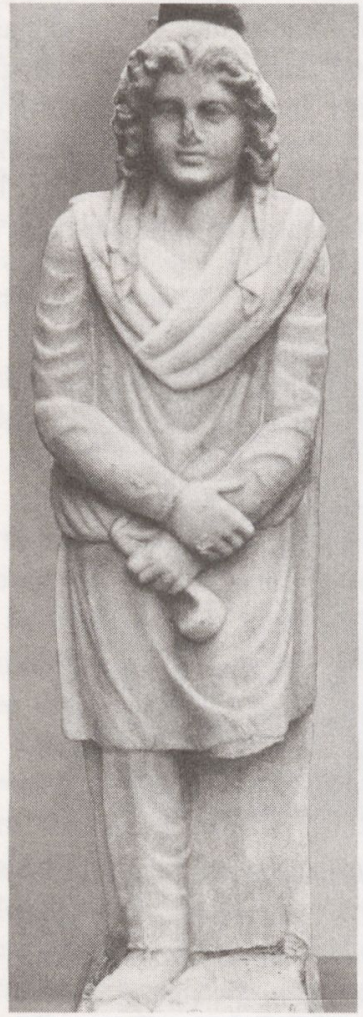

Fig. 10 Marble table-leg (H $74 \mathrm{~cm}$ ). Oriental servant with wine ladle. From Pompeii, Casa del Camillo (VII.12.2227, room “e”). Roman, c. CE 50-70. Naples, Museo Archeologico Nazionale.

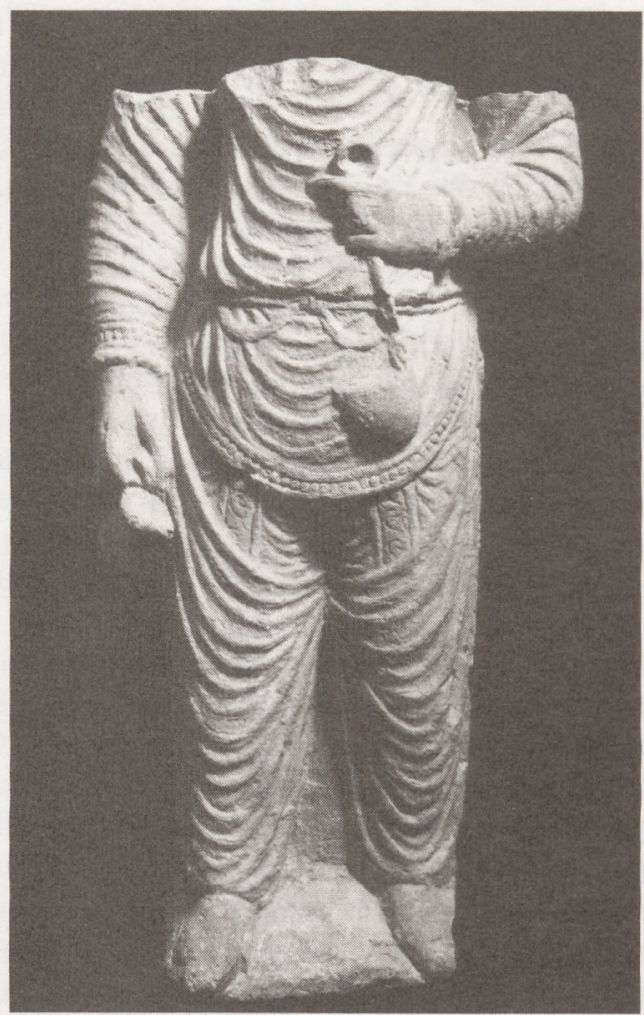

Fig. 11 Stone figure (H $44 \mathrm{~cm}$ ). Parthian servant with jug and wine ladle. From Palmyra, c. second century CE. Palmyra, Museum.

In an ode dedicated to Agrippa's steward Iccius in 25 BCE, the Augustan poet Horace confirms the desirability of such handsome Oriental cup bearers. The poet refers to the alluring prospect of great wealth and a luxurious life-style when Iccius returns home after his victories over the Arabs, the Parthians perhaps even over the Chinese:

What page from (Oriental) court with scented locks will be set to hand your wine cup? ${ }^{48}$

At Rome, the image of the Oriental cup bearer with a wine ladle was closely related to that of Ganymede, the most beautiful cup bearer of all. ${ }^{49}$ This prince 
was associated with both his homeland Troy and neighbouring Phrygia. ${ }^{50}$ To show the beauty of his body he was conventionally portrayed naked except for a mantle and Phrygian cap. ${ }^{51}$ The Phrygian cap probably alludes to the fact that he was a Trojan, especially as Trojan and Phrygian had been (subtly) interconnected ever since the fifth century BCE. ${ }^{52}$ On Roman Republican coins, Roma herself is occasionally depicted with a Phrygian helmet, no doubt in allusion to the city's claimed Trojan origin. ${ }^{53}$ The close connection of the Phrygian cap with Troy in early imperial times is confirmed by Juvenal. He describes it as part of the dress of the flamboyantly foreign Galli, the selfcastrated attendants of the Mater Magna in Rome and elsewhere. ${ }^{54}$ Just like the figures of Oriental cup bearers, sculptures of Ganymede often served in Roman villas as table legs. ${ }^{55}$ The handsome Trojan prince is usually accompanied by an eagle, recalling his abduction to Olympus by Zeus and his fate eternally to serve wine to the gods. ${ }^{56}$ Zeus' Trojan cup bearer was the mythical archetype of the historical slave cup bearer from the East. Both alike betoken the ability of the Roman élite to command all the resources of the empire in the endlessly enjoyable task of projecting and maintaining their rank. ${ }^{57}$

\section{The Trojan: the Oriental forefather of Rome}

The Augustan statue of Ganymede at the stately villa at Sperlonga, on the coast about 70 miles south of Rome, opens up a further discourse regarding the relations between Rome and the Orient (Fig. 12): ${ }^{58}$ for it is not only the earliest known Roman representation of the beautiful Trojan boy but also the only one wearing Oriental dress. The statue was erected above the entrance to a cavern, which served as the large villa's dining hall. It was based on a plinth specially fitted into the rock, and so occupied a spectacular setting overlooking the sea (Fig. 13). ${ }^{59}$ Giving every appearance of having arrived straight from Olympus, the statue was designed to combine élite workmanship and setting with a new interpretation of Roman Orientalism: Ganymede here is not small but larger than life, he is displayed not indoors but as a landmark outside and appears not naked but in rich Oriental dress. Furthermore, he is made not of monochrome stone but polychrome marble from his Phrygian homeland in contrast to the head and the lost hands of white marble. The exceptional position of the statue must have demanded a specific reading. The statue is in fact the only known depiction of the handsome shepherd as distinctively Trojan. ${ }^{60}$ In this way the statue was irrevocably linked to the four major marble groups located inside the grotto, which depicted distinctive incidents from the epic cycle: Aiax' rescue of the dead Achilles, Troy's most deadly enemy; Diomedes' and Odysseus' theft of the sacred Palladium which later secured the primacy of Rome; Odysseus' blinding of the monster Polyphemus; and Odysseus' fight against Scylla's dreadful attack on his ship. ${ }^{61}$ The juxtaposition was evident. The ancient viewer would have understood the compelling message(s) of the sculptural dramas 
loaded with the Augustan ideology of Rome's Trojan descent: the owner of the villa claimed that the epic cycle was a crucial part of Rome's history, and that the selected epic incidents were staged and shaped in a way only the Roman élite was able to achieve.

In Sperlonga the myth of Roman Troy stimulated the production of some of the most remarkable and meaningful narratives related to the Trojan War. As a Trojan, Ganymede was a mythic ancestor of Rome, however, as an Oriental servant on Olympus he was a model to embody the service owed by the East to the Roman élite. The statue at Sperlonga neatly combines the paradoxical themes of friendship and enmity, Roman and Oriental. This makes the Sperlonga statue of Ganymede a case in point regarding the ambivalent aspects of Roman Orientalism. ${ }^{62}$ The special relationship between the Roman élite and the Trojan Ganymede

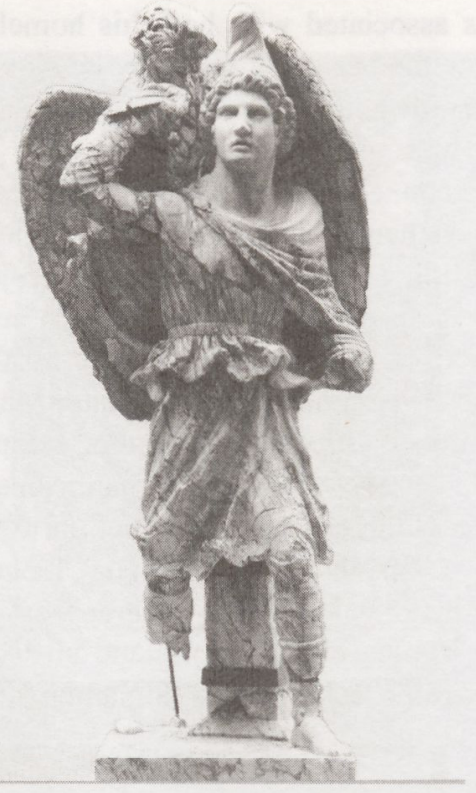

Fig. 12 Statue made of "marmor Phrygium" (H 2.25 m). Ganymede in the clutches of Zeus' eagle. From the villa in Sperlonga. Roman, c. 20 BCE - CE 10. Sperlonga, Museo Archeologico.

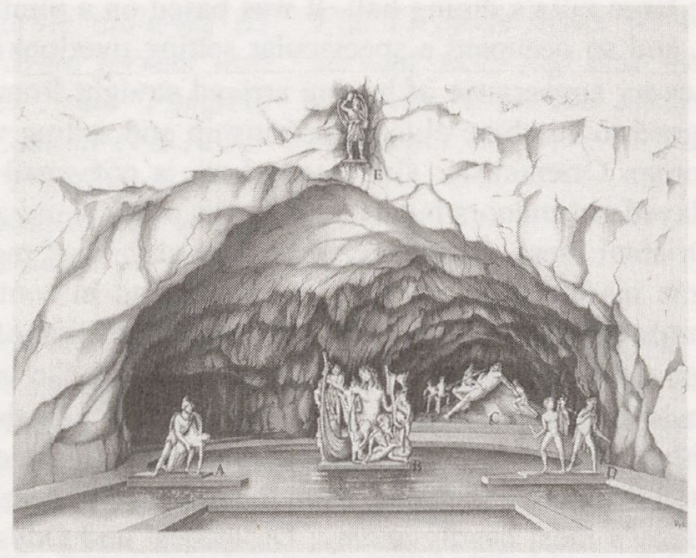

Fig. 13 Reconstruction of the grotto at the villa in Sperlonga, showing the statue of Ganymede (see Fig.

12) in its original position over the entrance. 
was later propagated by the mint at Ilium: portraits of Hadrian, Marcus Aurelius and Commodus on the obverse were complemented by images of Ganymede with Zeus' eagle on the reverse. ${ }^{63}$

In Augustan imagery Rome's claim to both her Oriental origin and her supremacy over the Orient was pushed even further. Classical scholars have given little attention to the fact that the handsome Oriental was also used to represent the Oriental "half" of Rome's (multi-)cultural identity. This is especially true of the imagery of the most distinguished monuments set up in the early imperial city. A key role in representing Rome's Oriental half was given to the Trojan prince Iulus/Ascanius, the son of Aeneas. Aeneas, the son of Aphrodite, had saved his father Anchises and his son Ascanius when he abandoned burning Troy to contribute to Rome's foundation. ${ }^{64}$ The Roman poet Vergil renamed Ascanius in order to relate him by name to Augustus' adoptive family, the Iulii (Aeneid I.267-268, 286-289):

His son Ascanius, whose surname is now Iulus Ilus it was, before the realm of Ilium (= Troy) fell $-\ldots$

From the fair seed of Troy there shall be born a Caesar Iulius, his name derived from great Iulus - whose empire Shall reach to the ocean's limits, whose fame shall end in the stars. He shall hold the East in fee ... ${ }^{65}$

Iulus/Ascanius, as the youngest Trojan, had passed his Trojan lineage on to Rome. From the Augustan period onwards he was usually portrayed in Oriental dress. One of the first Roman depictions of Iulus/Ascanius occurs on the external frieze to the right of the main (western) entrance of the Ara Pacis Augustae (Fig. 14) ${ }^{66}$ Entirely built of marble, the Ara Pacis was commissioned by the Roman senate in 13 $\mathrm{BCE}$ to celebrate the victorious return of Augustus to Rome from military campaigns in Spain and Gaul. ${ }^{67}$ Outstanding in the richness and subtlety of its sculpted décor, the Ara Pacis portrays the chief concerns of the Augustan order: Roman gods, depictions of sacrificial rituals and public processions, representations of religious symbols and the fecundity of nature as a metaphor of the

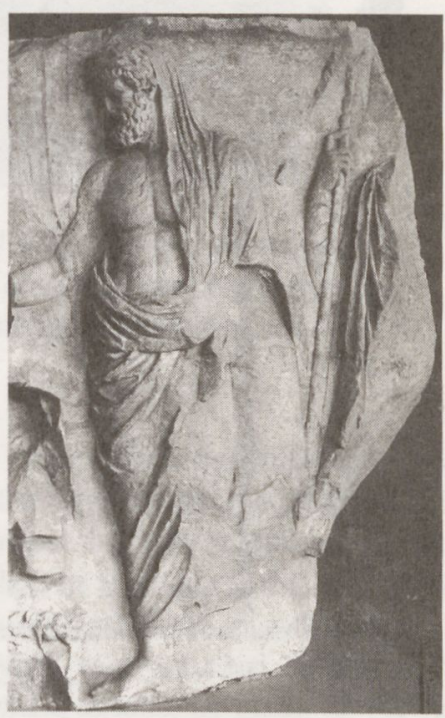

Fig. 14 Rome, Ara Pacis Augustae. Relief to the right of the main entrance. Aeneas, behind him Iulus/Ascanius (partly extant). Roman, 13-9 BCE. 
Augustan Golden Age. ${ }^{68}$ Despite the fragmentary state of the frieze, it is clear that Iulus/Ascanius stands, a grown man, to the right of (that is, behind) his father Aeneas, holding a shepherd's crook. In contrast to the old-fashioned Roman toga of his father, Iulus/Ascanius is shown in a long-sleeved tunic, a mantle and (perhaps) long trousers. ${ }^{69}$ His Oriental origin would have been further highlighted by the distinctive (but now lost) colouring of his Trojan dress.

The most crucial Roman portrayal of Iulus/Ascanius, however, was displayed in the Forum Augustum, which was dedicated in 2 BCE (Fig. 15). ${ }^{70}$

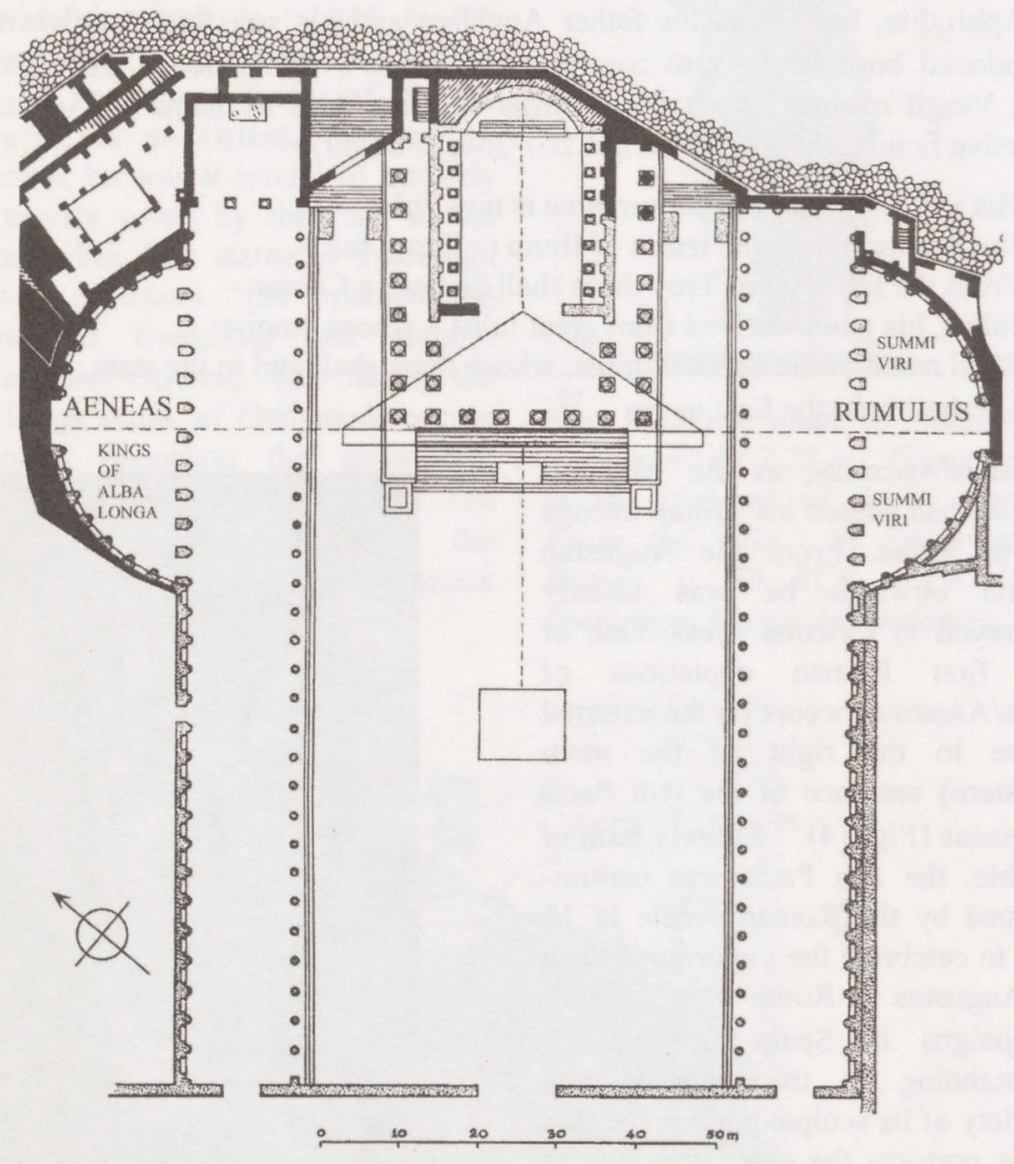

Fig. 15 Rome, plan of the Forum Augustum. The southwestern half is a hypothetical reconstruction ( $L$ c. $125 \mathrm{~m}, W$ c. $118 \mathrm{~m}$ ). Dedicated 2 $B C E$.

The Forum Augustum was a space which transmitted the ideology of the imperial régime in exceptional complexity, workmanship and choice of marble. 


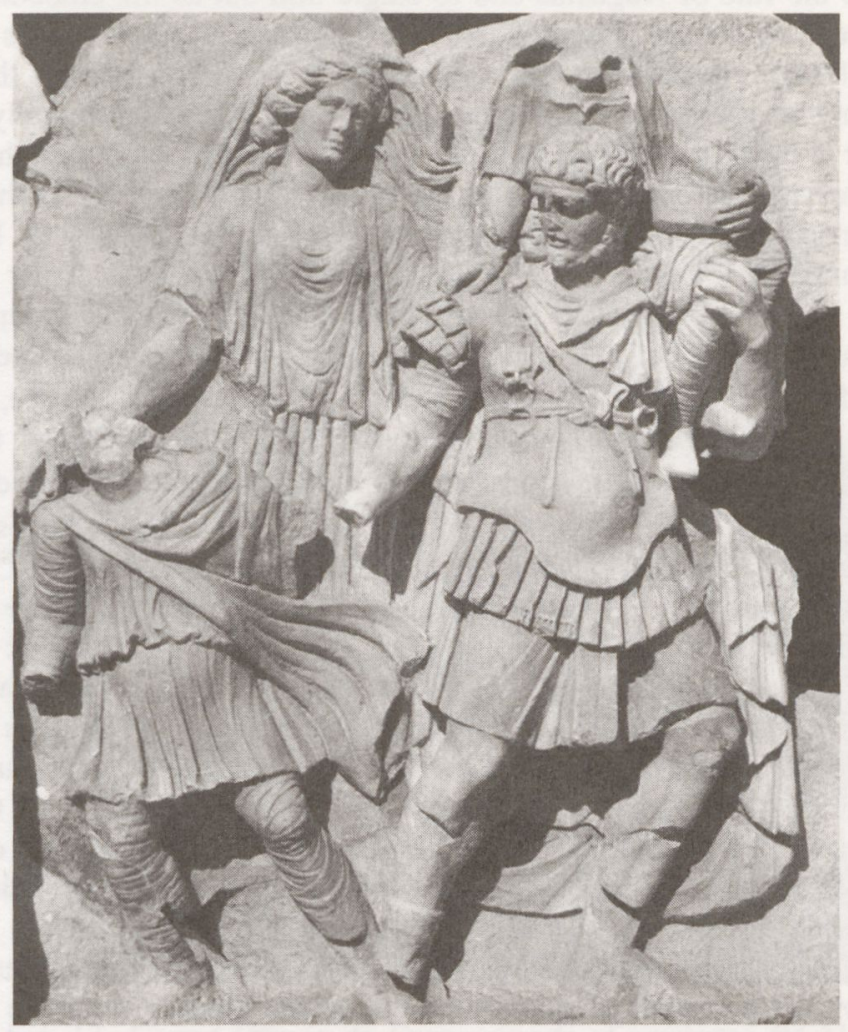

Fig. 16 Marble relief ( $H$ c. $1.6 \mathrm{~m}, \mathrm{~W}$ c. $1.6 \mathrm{~m}$ ). Aeneas carrying his father Anchises and holding the hand of his son Iulus/ Ascanius. In the background Aphrodite. From Aphrodisias, Sebasteion. Roman, c. CE 20-60. Aphrodisias, Museum.

The Forum's temple was dedicated to Mars Ultor. Mars was the Roman god most closely associated with the myth(s) of the Oriental origins and the Italic pre-history of Rome. In the Republican period he was supposed to have impregnated Ilia/Rhea Silvia, a direct descendant of the House of Aeneas. ${ }^{71} \mathrm{He}$ could thus claim to be the father of Romulus and Remus and, hence, an ancestor of all Romans. At the same time Mars was regarded as one of the oldest gods of Rome. Together with Jupiter and Quirinus, he made up the first Capitoline triad said to have been established in Archaic times. ${ }^{72}$ Furthermore, Mars' new cognomen ultor (= avenger) referred to all the enemies plotting against Rome and her new emperor, with explicit reference to the Parthians. ${ }^{73}$ The Forum Augustum itself was extremely rich in imagery. ${ }^{74}$ Marble portrayals of the most noble Romans (summi viri), historical and mythical, were selected 
to celebrate the rule of Augustus and to single him out as the embodiment of Rome's legendary history. The climax of the sculptural programme was marked by two colossal images that are considered to have represented the most important mythical ancestors of Rome. They were placed conceptually facing one another in the central niches of the Forum's two large exedrae: to the south, Romulus carrying the emblems of Rome's history (spolia opima); to the north, Aeneas carrying his father Anchises out of Troy and leading his son Iulus/Ascanius by the hand. The originals have not survived. Their general appearance is, however, attested by more than a hundred and sixty adaptations, not only in sculpture but also on mosaics, wall paintings, coins, gems and lamps. ${ }^{75}$ After a thorough re-examination of the surviving evidence, Martin Spannagel has been able to outline the iconographic concept of the lost originals. ${ }^{76}$ A good idea of the appearance of the Trojan group is provided by a relief in the Carian city of Aphrodisias (Fig. 16) ${ }^{77}$ The relief embellished the city's Sebasteion, a processional cult complex built roughly between CE 20-60 and dedicated jointly to the city's patron goddess Aphrodite and the Roman emperors. Each of the three Trojans is given a different cultural body: Aeneas is depicted as a Roman general in a Roman cuirass - only his old fashioned beard identifies him as a mythical hero; his father Anchises is shown in a mixture of foreign and Graeco-Roman dress, namely trousers, tunic and mantle; while Aeneas' son Iulus/Ascanius is dressed entirely in Oriental fashion. Behind them is Aeneas' mother Aphrodite. She connotes not only the political bonds between Aphrodisias and Rome but also the magnitude of the Trojan-Julian connection in shaping the identity of imperial Rome.

Another programmatic statement about Rome's Oriental identity is conveyed by the portrayal of Iulus/Ascanius on the Grand Camée de France, the largest surviving cameo from antiquity (Fig. 17). ${ }^{78}$ Made of exotic sardonyx and probably carved around $\mathrm{CE} 23 / 24$, it constitutes an outstanding political manifesto designed for exclusive use at the imperial court in Rome. The Oriental is the only person present in all three panels, which divide the cameo's narrative in vertical hierarchy. ${ }^{79}$ The bottom panel is the smallest, and the only one to be rigorously separated from the other two. It depicts the edge of the world populated by defeated barbarians from the East, the West and the North. The middle panel is the largest. It shows a controversially discussed dynastic constellation. Clearly identifiable, however, is the sitting couple at its centre, the emperor Tiberius and his mother Livia. The upper panel emerges immediately from the middle panel and represents deceased members of the imperial family in cosmic space. The most prominent of them is Divus Augustus, who is portrayed at the highest point, in the centre, carried on the back of an Oriental suspended over the current emperor. The Oriental is holding with both hands a celestial sphere, the very symbol of Roman power. ${ }^{80}$ 


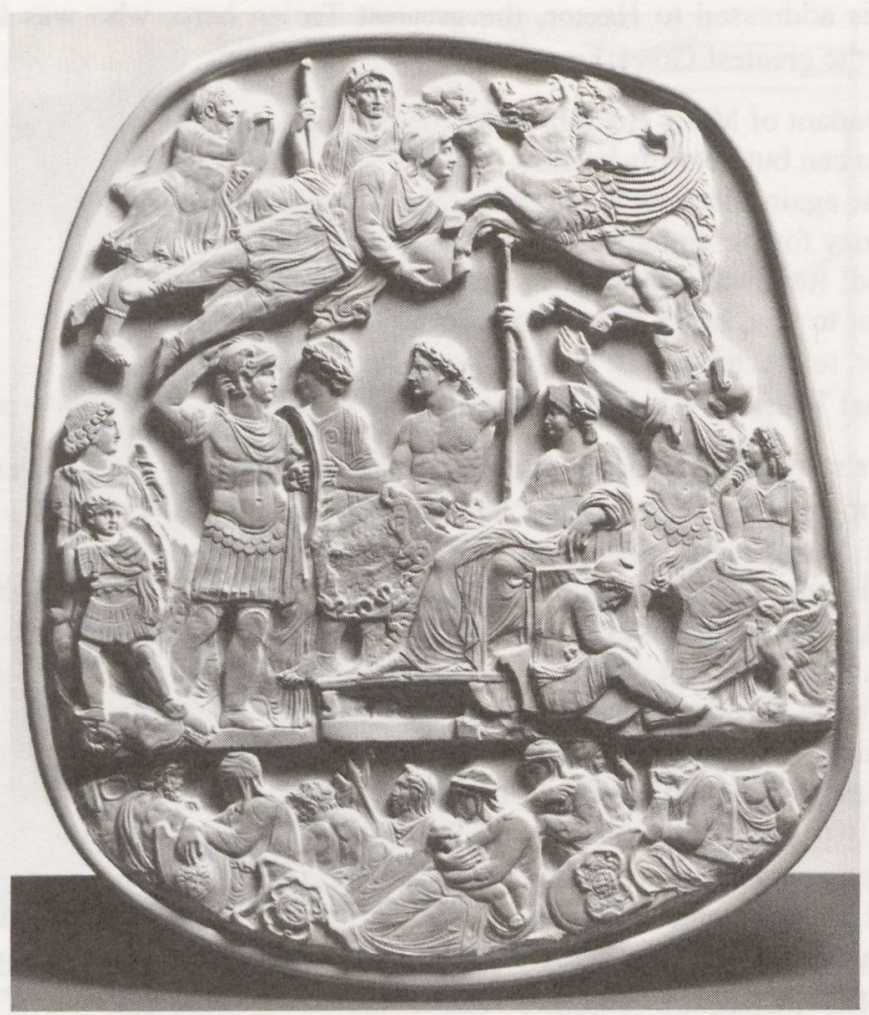

Fig. 17 Grand Camée de France made of sardonyx (H $31 \mathrm{~cm}$, $W 26.5 \mathrm{~cm})$. In the centre Tiberius and Livia seated, above them Iulus/Ascanius in Oriental dress carrying Divus Augustus. Roman, c. CE 23-24. Paris, Bibliothèque Nationale.

Recently Luca Giuliani has (re-)read the visual narrative of the cameo and (re-)established that the handsome Oriental must be Iulus/Ascanius. He is, as the Trojan ancestor of Rome's mythical founder(s), the most suitable person to carry Divus Augustus, the founder of imperial Rome. ${ }^{81}$

At Rome images of Trojans can be traced back to the fourth century BCE. ${ }^{82}$ However, only in the Augustan period were the myth of Troy and the imagery of the Oriental as Trojan made a cornerstone of Roman imperial ideology. ${ }^{83}$ The Orient became a crucial element of Rome's imperial identity, and as such her indisputable property: hence, Rome could claim the East her own. One of the most remarkable statements of this ideology is an epigram attributed to Germanicus, the step-nephew of Augustus. He wrote the poem on his visit to Ilium (built on the site of ancient Troy) in CE 18 on his tour of inspection through the Eastern provinces that ended with his unexpected death. ${ }^{84}$ The 
epigram is addressed to Hector, the greatest Trojan hero, who was killed by Achilles, the greatest Greek hero: ${ }^{85}$

Descendant of Mars, Hector, under the deep(est) earth

(if you can but hear my words),

breathe again, since an avenger has come to you as heir, who may forever enhance the fame of your fatherland.

Behold! Renowned Ilium rises again, a race inhabits her inferior to you, Mars, but nevertheless a friend of Mars.

Hector, tell Achilles that all the Myrmidons have perished

and that Thessaly is under the sway of the great descendants of Aeneas. ${ }^{86}$

Hector's avenger is none other than Rome who ultimately avenges the devastation of Troy. ${ }^{87}$ Following the death of Hector only Augustus and the people of Rome were considered to be descendants of equally Mars and the Trojans. Hector's newly acquired ancestry from Mars would have underlined the fact that the Trojans and the Romans shared the same descent. According to the poem, Rome has not only revived the legendary power of Troy but has also achieved rule over Greece, Troy's arch-enemy, represented here by the descendants of Achilles' Myrmidons in Thessaly. Such claims emphasise once more the gripping quality of the image of the handsome Oriental that brought together two distinctive aspects of Rome's (Augustan) identity, her actual imperial present and her mythical Trojan past. ${ }^{88}$ Only two Trojan princes were portrayed as handsome Orientals in early imperial Rome: Ganymede as the most noble and desirable servant ever, and Iulus/Ascanius as the youngest eastern representative of both Troy and Rome.

\section{Augustan Rome and the Persian Wars}

Two further motifs of the handsome Oriental were introduced into the imagery of Augustan Rome: standing (Figs. 21-22) or kneeling (Figs. 18-19) sculptures in the gesture of support. ${ }^{89}$ Both statue types are over life-size and mostly made of coloured marble. In the Renaissance, however, hands and faces were often restored suggestively but wrongly in black marble. ${ }^{90}$ Originally these parts of the body were carved separately in white marble as shown by the statue of Ganymede in Sperlonga (Fig. 12). In the Augustan period these "support" figures were related to both the Parthians and the Persians. Following a standard set by Cicero, Augustan poets such as Vergil, Propertius, Horace and Ovid usually refer to the Parthians by the name of their historical ancestors, Medes, Persians or Achaemenians. ${ }^{91}$ The Persian Wars of the fifth century BCE legitimised not only Alexander's invasion of the Achaemenid empire (335/334 BCE) but also Rome's politics towards Parthia. After the return of the standards in $20 \mathrm{BCE}$ the equation of the Parthians with the Persians became a focal point of imperial ideology. ${ }^{92}$ 


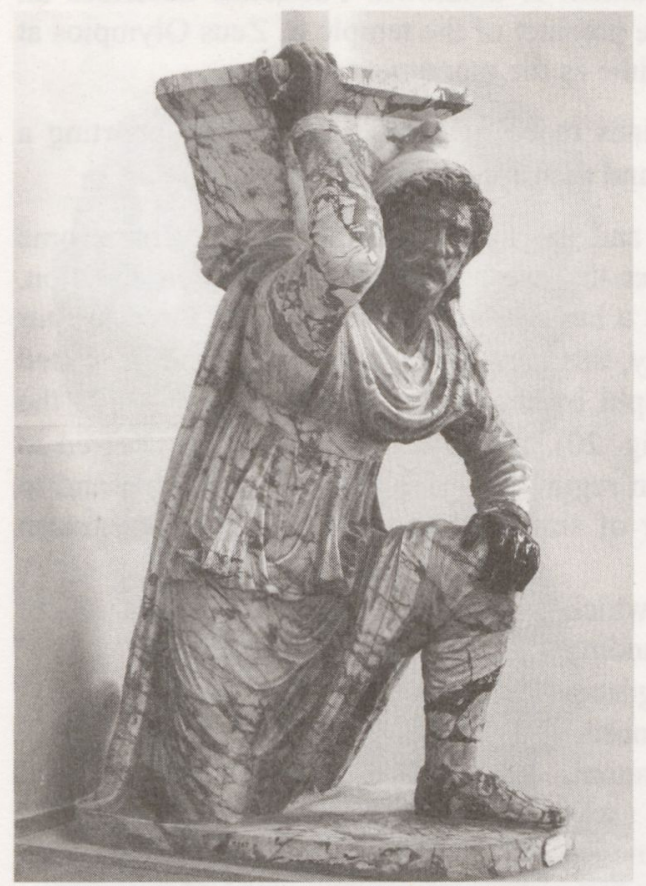

Fig. 18 Statue made of "marmor Phrygium" $(H$ c. $1.70 \mathrm{~m})$. Kneeling Oriental. From Rome. Roman, c. 20-10 BCE. Naples, Museo Archeologico Nazionale.

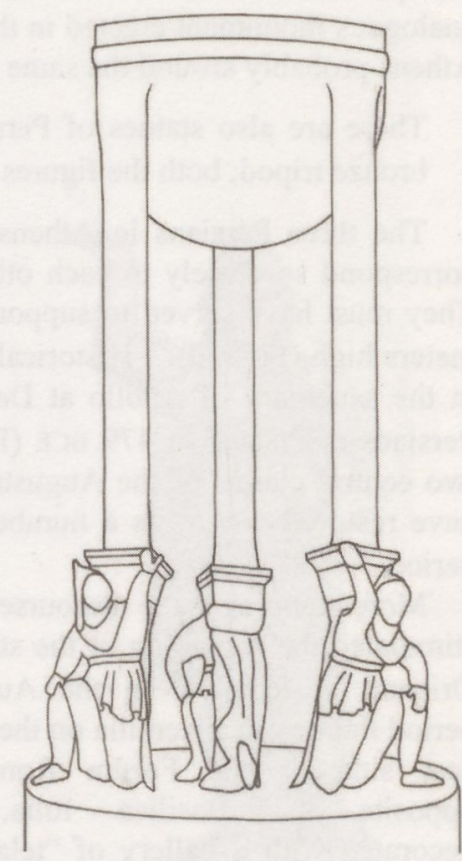

Fig. 19 Reconstruction of a victory monument (now lost). Originally in Rome and Athens ( $H$ at least $4 \mathrm{~m}$ ). Three kneeling Orientals made of "marmor Phrygium" (see Fig. 18) carrying a bronze tripod. Roman, c. 20-10 BCE.

A visual highlight of this ideology was the grand spectacle of a sea battle, the naumachia Augusti, staged to celebrate the dedication of the Forum Augustum in 2 BCE. The battle took place in a specially excavated basin measuring $540 \times 360 \mathrm{~m}$ (approx. 48 acres!) and was fed by a purpose-built aqueduct. In addition to an unknown number of oarsmen, roughly 3000 fighters were forced to re-enact the victory of the Athenian navy over the Persian (in reality largely the Phoenician) fleet at Salamis in 480 BCE. ${ }^{93}$

A victory monument, now lost, was erected (shortly) after 20 BCE. It can be reconstructed on the basis of two different sources: a brief phrase by the imperial Greek writer Pausanias, and three statues of kneeling Orientals. They form one set as they share not only the same size, motif, Phrygian marble and Augustan workmanship but also the same origin, the city of Rome (Fig. 18). ${ }^{94}$ 
The precise location of this monument is unknown. Pausanias describes an analogous monument erected in the precinct of the temple of Zeus Olympios at Athens probably around the same time as the monument in Rome:

There are also statues of Persians made of Phrygian marble supporting a bronze tripod; both the figures and the tripod are worth seeing. ${ }^{95}$

The three Persians in Athens and the three kneeling figures from Rome correspond so closely to each other that we are able to define their function. They must have served to support a large bronze tripod, at least three to four meters high (Fig. 19) ${ }^{96}$ Historically, this tripod referred to the tripod dedicated in the sanctuary of Apollo at Delphi by those Greek cities that defeated the Persians at Plataea in 479 BCE (Fig. 20). ${ }^{97}$ Politically, however, it referred to two central claims of the Augustan regime: to have "defeated" Parthia and to have restored pietas, as a number of similar tripods appear in the Augustan period. $^{98}$

More complex is the discourse which stimulated the reshaping of the standing Oriental in Rome. ${ }^{99}$ In the Augustan period the Basilica Aemilia on the northeast side of the Forum Romanum, opposite the Basilica Iulia, was decorated with a gallery of "telamons" all showing standing Orientals; their original location in the basilica is unknown. ${ }^{100}$ Fragments (none of them published) of about twenty or more over life-size statues of Orientals in coloured marble have survived (Fig. 21). ${ }^{101}$ All are in the same weighted stance and are worked to an exceptional finish. The style links the Orientals to the restoration of the Basilica Aemilia after 14 BCE; since the restoration was paid for by Augustus and the friends of Lucius Aemilius Paullus (Dio Cassius 54.24.3) we may suspect an allusion to the return of the standards in 20 BCE. As the ancient arms of the sculptures are in part lost we need to reconstruct their original pose. The evidence suggests that they were "telamons" with one arm in the gesture of support: the upper arm was outstretched sideways, the lower arm raised upwards and the hand again

Fig. 20 Reconstruction of the Delphian tripod ( $H$ c. $12 \mathrm{~m}$ ). Dedicated at the sanctuary of Apollo at Delphi by the Greek cities that defeated the Persians at Plataea in $479 B C E$. 


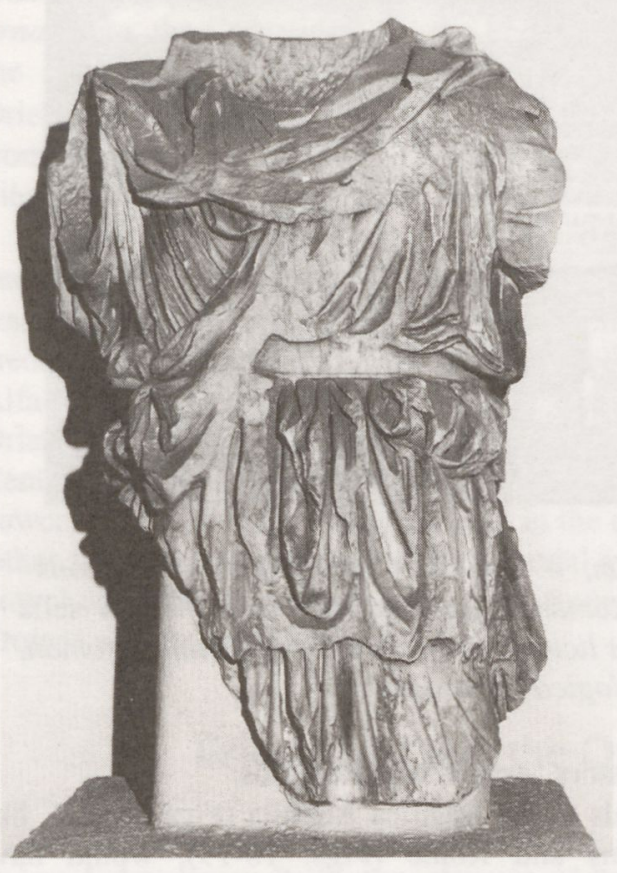

Fig. 21 Torso made of "marmor Phrygium" Fig. 22 Reconstruction of the (H $1.10 \mathrm{~m}$ ). Standing Oriental ("telamon") support gesture of the standing originally shown in the gesture of support Oriental from the Basilica (see Fig. 22). From Rome, Basilica Aemilia. Aemilia (see Fig. 21).

Roman, after 14 BCE. Rome, Antiquario

Forense.

outstretched to the side (Fig. 22). ${ }^{102}$ The weighted stance and the position of the arm highlight a semantic construction of this mannered pose: the standing Oriental virtually embodies the tectonic counter-model of any telamon used to support architecture. The result is a visual combination of an active Oriental servant with the desirable Oriental youth, perhaps related to the ideology of Parthia's "defeat" in 20 BCE. A further reading is suggested by the Latin names recorded for the Orientals: Pliny the Elder calls them Phryges. ${ }^{103}$ Although imperial texts use Phryx occasionally as synonym for Oriental slave, it is tempting to understand Pliny's Phryges also as a synonym for the Trojan ancestors of Rome - a synonym especially popular in the early imperial city. ${ }^{104}$ This interpretation may be supported by the long frieze, which, together with the gallery of the standing Orientals, decorated the Augustan basilica. The frieze dealt with the (mythical) history of Rome, namely selected 


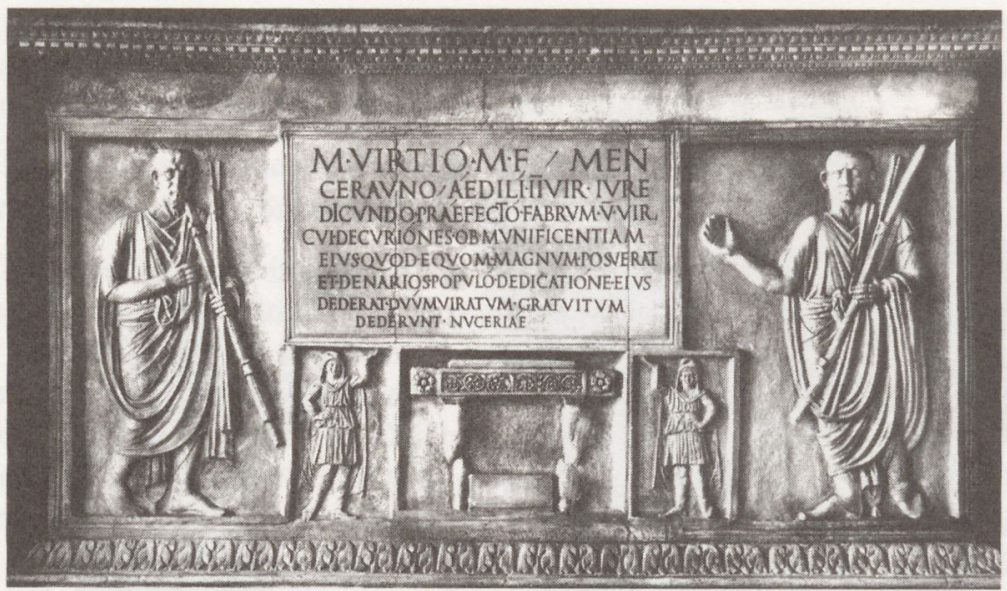

Fig. 23 Marble relief (H 1.95 m, W $3.52 \mathrm{~m}$ ). Two Oriental "telamons" support the inscription of a Roman magistrate, between them a sella curulis, next to them two Roman lictors. From Nuceria Alfertana. Roman, c. CE 60. Naples, Museo Archeologico Nazionale.

narratives of Rome's famous ancestors, Aeneas and Romulus. ${ }^{105}$

However, the standing Orientals of the Basilica Aemilia (Figs. 21-22), like the kneeling Orientals in Athens and Rome (Figs. 18-19), would have stimulated the viewer also to compare the Roman settlement of the Parthian question in 20 BCE with the fifth-century Greek victories over the Persians. The architect Vitruvius, who practised under Caesar and Augustus, confirms the topicality of the standing Oriental as an image referring to the Persian Wars. At the beginning of his ten books on architecture he summarises the essentials an architect ought to know, "the thing signified, and that which gives it significance" (de architectura 1.1.3). "Vitruvius names only two examples of architectural ornamenta the history of which an architect ought to know, first the Caryatides (1.1.5) and then the telamons of Persians (1.1.6):

the Laconians ... after overcoming with a small force a large army of Persians at Plataea celebrated a glorious triumph with spoils and plunder. And they erected the Persian Stoa from the booty instead of the usual victory memorial for the coming generations to signify the glory and the virtue of the citizens. In this stoa they placed statues of their captives dressed in rich barbaric dress to support the roof - their pride punished by well-merited humiliations. This was done for two reasons: to make their enemies tremble for fear of what Laconian bravery could achieve, and to prompt their fellow-citizens to look at this model of virtue and, encouraged by such glory, to remain ready to defend their freedom. And so from that time many have set up Persian statues to support architraves and their ornaments ... ${ }^{107}$ 
The only popular Roman statue of a Persian depicted in the form of a telamon is the standing Oriental. It is hardly a coincidence, that both ornamenta, the Caryatides and the Persians, selected by Vitruvius to highlight the architect's historical knowledge, were closely related to narratives of Orientalism. ${ }^{108}$ Vitruvius' choice is significant as he excluded other ornamenta from pre-Augustan architecture, telamons such as Atlantes, Giants, Satyrs and Sileni, and sculpted components such as pediments, metopes and friezes.

The image of the standing Oriental was popular throughout the Roman empire. ${ }^{109}$ Of particular interest is a marble relief now in Naples (Fig. 23). ${ }^{110}$ It was carved around CE 60 to decorate the front of a prestigious grave monument erected for Marcus Virtius Ceraunus, once aedilis and duumvir of Nuceria Alfaterna, a Campanian town situated east of Pompeii. Two small standing Orientals look as if they are supporting the inscription that proudly reports Ceraunus' local career. They are dwarfed by two insignia of Roman imperial power, the curule chair (sella curulis) in the centre, and the ushers (lictores) on either side. Closely attached to the imperial symbols the two Orientals probably provoked ambivalent readings ranging from captive Parthians to "supporting" Trojans and desirable servants.

\section{Friend and foe: the Orient in Rome}

From the Augustan period onwards ethnic Parthians and handsome Orientals became a distinctive element of Roman imagery. They were widely adopted throughout the Roman empire and not restricted to the periods of actual war between Rome and Parthia. ${ }^{111}$ They were continuously popular not only with Roman emperors and members of the Roman and non-Roman élite, but also with worshippers of eastern deities like Attis (Fig. 24) and Mithras (Fig. 25). The popularity of these images is further enhanced by the difference between images of the handsome Oriental and those of other non-Romans. In contrast to other portrayals of non-Romans the handsome Oriental combines an allusion to servitude with desirable beauty and all the connotations of coloured marble. In Augustan Rome these features were brought together for the first time and set up as a standard for future generations.

In the context of Augustan Orientalism the new staging of coloured marble acquired specific readings. The over life-size statues of the Oriental were worked in coloured marbles for the first time, and only the most expensive and exclusive varieties were used: the whitish marmor Phrygium, and the yellowish narmor Numidicum. Though they come from different parts of the Mediterranean, both appear similar as they are reticulated by veins, ranging from crimson to violet. Their exotic colour and high polish gave the Oriental body an intensity and meaning unprecedented in ancient art. ${ }^{112}$ The polychrome Orientals granted the East a new presence at Rome as "coloured" embodiments of eastern dress, attitude and luxury. This ideology of ethnicity, marble and colour was further increased as (most of) the polychrome quarries became 
imperial property under Augustus and produced polychromes on a large scale for the first time.

The quarries themselves were situated in distant provinces and required a complex infrastructure to deliver coloured marble to Rome: the imperial polychromes became a unique symbol of the power and cultural accomplishments Rome claimed to have achieved. As a result, the polychrome Orientals represented spoils never before seen at Rome. The display of such remarkable spoils would have reminded the ancient viewer of the Roman triumphal procession. ${ }^{113}$ This ritual was a potent demonstration of Rome's relationship to non-Roman cultures: by it foreign people and things were declared in public the property of Rome. By staging and incorporating other cultures Rome legitimised her claim to rule them all.

The complexity of Rome's relationship to non-Roman cultures is highlighted in the image of the handsome Oriental. Through it, Augustan patrons and workshops created a visual metaphor which was able to express very different claims of Rome's relationship to the East. The handsome Oriental embodied every character from the east, and there were many: mythical and religious figures such as Arimaspi, Attis (Fig. 24) with Cautes and Cautopator, Mithras (Fig. 25) and Orpheus; figures belonging to foreign cults in Rome such as the self-castrated Galli; figures of Rome's mythical past such as the attractive Trojan princes Ganymede (Fig. 12), Iulus/Ascanius (Figs. 14,16, 17) and Paris; fascinating Others such as the desirable youth and the beautiful servant (Figs. 10, 21-23); political personifications such as Armenia, Parthia and Mesopotamia; past and current enemies such as the Persians, the Parthians and the Armenians (Figs. 2-3, 5-7, 9, 18, 21-23), and later also the Sasanians. ${ }^{114}$ The "Oriental revolution", which according to Warwick Ball represents a crucial factor in the development of the later Roman empire had already happened in Augustan Rome: her "legacy is as much eastern and western, as much oriental as occidental, both to Europe and the world as a whole". ${ }^{115}$ However, our modern political notions of friend and foe, of Occident and Orient, based as they are on a Hegelian reading of the bipolarity of force and counterforce, fail to fuse such apparently opposite social and cultural values.

This complexity of the Roman imagery of the handsome Oriental has caused modern scholars a methodological headache. A fine example is the dispute over the identity of the images of two children in foreign dress, one on the south, the other on the north frieze of the Ara Pacis. Both are shown taking part in the procession of selected members of the imperial family. ${ }^{116}$ Modern scholars have identified the children either as the two Augustan princes Gaius and Lucius Caesar in the costume of the lusus Troiae (an equestrian parade and mock battle staged by élite Roman boys), or as two of the Parthian princes who lived as hostages at the imperial court. ${ }^{117}$ On iconographic grounds both readings can stand. The foreign clothing of the two children, whether we interpret them as Gaius and Lucius Caesar in Trojan costume or as two Parthian 


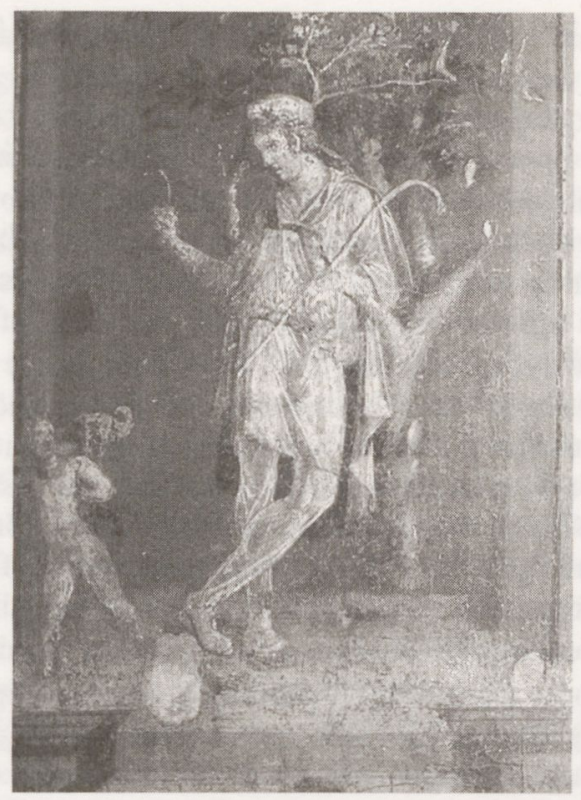

Fig. 24 Wall painting. Attis holding a sickle in his right hand. Roman, c. CE 70. Pompeii, Casa di Pinarius Cerialis (III.4.4).

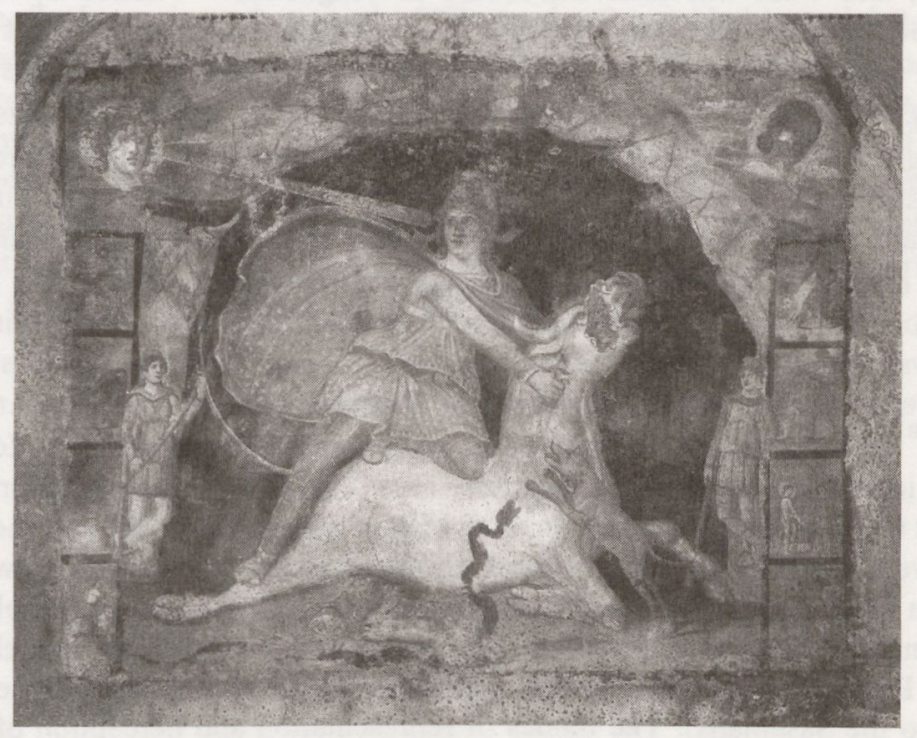

Fig. 25 Wall painting (H $1.80 \mathrm{~m}, W 2.50 \mathrm{~m}$ ). Mithras subdues the bull. Roman, c. CE 170. Marino, Mithraeum (in situ). 
or Armenian princes in eastern dress, refers to the Orient as a feature of Rome's cultural identity. ${ }^{118}$

How deeply the concept of the Oriental as friend was imprinted on the cultural identity of imperial Rome is particularly manifest in the widespread popularity of Oriental gods such as Attis and Mithras. ${ }^{119}$ Two images highlight the significance of visual narratives in the process of shaping and re-shaping Rome's Oriental identity throughout the principate. The first is a handsome, desirable Oriental on a fresco in a cubiculum of the House of Pinarius Cerialis in Pompeii, dated around CE 60 (Fig. 24). ${ }^{120}$ Only the sickle in his right hand identifies him as the god Attis. Otherwise the image shows a handsome Oriental dressed in luxurious, diaphanous clothes prompting a range of cultural, religious and gender-related readings. Different issues are at stake in the fresco of the god Mithras found in the Mithraeum at Marino near Rome, painted about CE 170 (Fig. 25). Here the focus is on the handsome image of Mithras in richly decorated, colourful dress, on his power as he subdues the bull, and the implied religious ritual. ${ }^{121}$ Modern scholars agree that, whatever its ultimate origin, the cult of Mithras in Rome was strongly based on Roman perceptions. ${ }^{122}$ Richard Gordon has recently argued that the cult contributed significantly to the maintenance of Roman socio-political structures, especially those of imperial power. ${ }^{123}$ The same is true of the major cult of the "Trojan" Mater Deum Magna Idaea. She had been worshipped in Rome ever since the second century BCE next to some of the city's most venerable sanctuaries, the legendary Hut of Romulus, and what was later the House of Augustus. ${ }^{124}$ Named by Vergil mother of the gods, she was not only Aeneas' great-grandmother but also, together with his mother Venus, the foremother of the Romans and Augustus. ${ }^{125}$ Ovid let Mater Magna follow Aeneas to Rome and calls him accordingly Phryx pius (fasti 4.274). ${ }^{126}$ This sheds further light on the role of Orientalism in the process of defining Rome's imperial identity and culture. The vibrant role of Rome's Orientalism is also mirrored in her late antique imagery, namely in the three Persian Magi of the Christian portrayal. ${ }^{127}$

In short, the (visual) preoccupation of Augustan (and later) Rome with the Orient was vigorous, perhaps even obsessive. Apart from the Greeks who themselves had been deeply influenced by Oriental cultures since the Archaic period, ${ }^{128}$ no other people contributed so profoundly to the shaping of Rome's imperial identity as the civilisations of the East. This is also true of the Oriental cults and their (western) imagery such as Magna Mater, Attis, Mithras and Isis, which were present in Rome almost throughout the principate. However, Augustan ideology had separated the multi-cultural East into two major blocks: on the one side Egypt, on the other side the eastern civilisations, namely the Trojans, Phrygians, Persians, Medes, Achaemenians, Parthians and Armenians (later also the Sasanians). The modes of representation and perception of both blocks in Rome were essentially different. From the Augustan period Egypt had become a distinctive part of Rome's urban imagery as the city became more and more inundated by looted Egyptian obelisks and sculptures; but Roman 
images of Egyptians themselves were not circulated. ${ }^{129}$ In contrast, Rome did not display pillaged artefacts from the other civilisations of the East. Instead she developed and diffused stereotypes of the eastern people, especially images of the ethnic Other and the handsome Oriental.

This focus on selected eastern civilisations in Rome's imperial imagery lent the portrayal of the cultural Other new significance. Here, the image of the handsome Oriental turned out to be a particularly successful icon as it became loaded with a set of different and inconsistent meanings. The image oscillated between Trojan friend, venerated Oriental deity and Parthian enemy, and embodied a strange conceptual overlap between the categories of friend and foe. ${ }^{130}$ For Rome, the Oriental as friend and the Oriental as foe were not two opposing poles. On the contrary, the discourse around them was one of the contexts in which Roman identity was defined. For Rome, "Roman" was synonymous with the world: a non-Roman could well become "Roman" but keep at the same time his own cultural identity. ${ }^{131}$ In this constantly shifting debate on the Roman and the Foreign, Mary Beard has rightly located the puzzling and contradictory Roman representation of the cult of Mater Magna. ${ }^{132}$ The different constructions of the role of the Orient(al) in Rome ranging from the legitimation of the city's eastern origin at Troy to the condemnation of Rome's most dangerous enemy, the Parthian - amounted to different claims and conflicting counterclaims on how "Roman" was to be defined. The definition of what was "Roman" could be described as a dynamic process driven by the political, religious, social and economic interests of Rome. Such a universal concept of "Romanism" provided imperial Rome with a powerful ideology which aimed at controlling the peoples of non-Roman cultures. The imagery of the handsome Oriental constituted a potent medium of communication which diffused and enhanced the ideology of Roman universalism throughout the Roman empire. This imagery shows perhaps more than any other medium, that the story of Rome is as much the story of the Orient as it is the story of the Occident. ${ }^{133}$ Or, in other words, imperial Rome made the Orient(al) as much her friend as her foe. 


\section{Acknowledgments}

I warmly thank Vesta Sarkhosh Curtis and Sarah Stewart for their kind invitation to London; my friends Luca Giuliani, Karl-Joachim Hölkeskamp, Susanne Muth and, especially, Richard Gordon for reading the manuscript and for stimulating criticism; Michael Alram, Bert Smith and the following institutions for benevolently providing photographs: Staatliche Museen zu Berlin, Preussischer Kulturbesitz, Antikensammlung, Berlin; Archäologisches Institut der Universität Köln, Forschungsarchiv für Antike Plastik (online photo service Arachne), Cologne; Museum für Abgüsse Klassischer Bildwerke, Munich.

\section{Photo Credits}

Fig. 1: Murken (1995), p. 42 fig. 43. - Figs. 2,3, 5, 7-10, 12, 14, 17-23: Museum für Abgüsse Klassischer Bildwerke, Munich. - Fig. 4: Invernizzi (2001), p. 230. - Fig. 6: Dawid (2003), frontispiece. - Fig. 11: Tanabe (1986), pl. 448; Fig. 13: Ulisse (1996), p. 68 fig. 23. - Fig. 16: Bert Smith (Oxford). Fig. 15: Zanker (1988), p. 194 fig. 149. - Fig. 24: Ghini (1994), p. 55. - Fig. 25: Pugliesi Carratelli (1991), 465 fig. 36b. 


\section{Notes:}

1. Fisch 1984; Hentsch 1988; Sievernich and Budde 1989; Shichiji 1991; Mackenzie 1995; Said 1995; Osterhammel 1998; Sardar 1999; Kurz 2000; Bohrer 2003. My thanks to Egon Flaig for drawing my attention to Ye'or's 2005 study.

2. For Occidentalism, Carrier 1992; Carrier 1995; Chen 1995; Ball 2000, pp. 448450; Buruma and Margalit 2005. - For the development of the concept of the West, GoGwit 1995a; GoGwit 1995b.

3. For friend and foe in (modern) European thinking, Hoffmann 1972; Palaver 1997.

4. Mitchell 1986; Brandt 1999; Scholz 2000; Waldenfels 2001; Smith 2002; Giuliani 2003: 9-19.

5. Orientalism and visual culture in the ninteenth century, Sosien 1995; Nochlin 2002; Bohrer 2003.

6. Murken 1995: 42, 44 fig. 43; Baumstark 1999: 414 fig. 258.

7. Murken 1995: 42-44 fig. 43; 47-50, 47-50; 91-92 fig. 83a; 106-107 figs 100c-d; Baumstark 1999: 406-449 ("König Otto und Königin Amalie: Hofstaat und monarchische Repräsentation"). For the eastern and western impacts on the Greek costume, Welters 1995; Papantoniou 1996: 127-133.

8. http://www.time.com/time/coversearch/.

9. Flügel 1930; Eicher 1995.

10. For Orientalism in the field of Classics, Dihle 1994; Schneider 1998; Hauser 2001; Kienlin and Schweizer 2002; Wiesehöfer 2003; Schneider 2006.

11. For foreignness at Rome, Noy 2000.

12. For recent studies on Rome's relationship with non-Romans, Mattern 1999; Ferris 2000; Burns 2003.

13. For this process, see also Beard 1994: 185-187.

14. See, however, Schneider 1998; Landskron 2005; Rose 2005; Schneider 2006.

15. For the Roman imagery of (northern) barbarians, Schneider 1992a; Zanker 2000: 410-419; Heitz 2003; Krierer 2004. - For western categories of cultural asymmetry, Koselleck 1975; see also Stevens 1994: 64-67 on C.G. Jung's concept of "shadow".

16. Timpe 1962; Ziegler 1964: 20-51; Timpe 1975; Schippmann 1980: 31-47; Malitz 1984; Sonnabend 1986: 159-227; Campbell 1993: 213-228; Butscher 1994: 447453; Wickevoort Crommelin 1995: 24-37; Ball 2000: 8-15; Wheeler 2002; Brosius 2006: 92-101.

17. See below n. 92 .

18. Schneider 1986: 29-97, 114-120, 128-130; Sonnabend 1986: 197-221; Zanker 1988: 183-192; Campbell 1993: 220-228; Rich 1998 ; Schneider 1998 ; Landskron 2005: 102-151; Rose 2005.

19. Schneider 1986: 31-32, 36, 71; Wallace-Hadrill 2004.

20. For a comparison of the two superpowers, Howard-Johnston 1995; Winter and Dignas 2001; Wiesehöfer 2003, who is also discussing the ideological preconceptions of such a comparison; Schneider 2006.

21. For potential pre-Augustan images of Parthians in Rome, Schneider 1998: 95.

22. Kähler 1959; Zanker 1988: 188-192; Simon 1990: Boschung 1993: 179-181 no. 171 (bibl.); Schneider 1998: 97-99; Wiesehöfer 2002; Rose 2005: 25-27.

23. Rose 2005: 25-26 has proposed identifying the representative of Rome not as Mars Ultor (opinio communis) but as Roma because of the Attic helmet, the "female" strands of hair which escape from the helmet, the "female" anatomy of the body and the dog. The identity of either Mars or Roma, however, is difficult to confirm. 
24. Brinkmann and Wünsche 2003: 186-197 (P. Liverani), with a reconstruction of the original colouring of the statue.

25. Calmeyer 1980 .

26. For further evidence, Schneider 1998: 98; Landskron 2005: 93-101. See also in this volume, V. S. Curtis: 16.

27. Mathiesen 1992: 166-167 no. 80; Invernizzi 200: 230 colour ill.; Landskron 2005: 95-96.

28. Hölscher 1988: 537-541; La Rocca 1992: 411-414; Schneider 1998: 100.

29. Schneider 1998: 100; Dawid 2003.

30. Dawid 2003: 55-63 pls. 6.19, 10.32a-c.

31. Binsfeld 1983; Schneider 1998: 101-102.

32. For the Phrygian cap, see below n. 51.

33. For Roman bars of gold, Göbl 1978: 145-146 pls. 39 nos. 476-477 (here fig. 8).

34. See below n. 113.

35. Sonnabend 1986: 254-260; Nedergaard 1988; Spawforth 1994: 242.

36. Suetonius, vita Augusti 43.4; for the context, Nedergaard 1988: 108-109.

37. Further evidence in Sonnabend 1986: 188, 241; Spawforth 1994: 260-263; Krumeich 2001: 88-92; Rose 2005: 36-37.

38. Sonnabend 1986: 235-246, 264-272, 282-286; Campbell 1993: 216-220; Wiesehöfer 1996: 123-124; Schneider 1998: 103.

39. Paratore 1966: 505-558; Sonnabend 1986: 172, 280-282.

40. Florus, Epitomae 1.40.31 (Sic Pompeio duce populus Romanus totam ... Asiam pervagatus, quam extremam imperii habebat provinciam mediam fecit. Exceptis quippe Parthis ...); Pompeius Trogus, Historiae Philippicae 41.1 .1 (divisione orbis); Manilius, Astronomica 4.674-675 (orbis alter; Tacitus, annales 2.2.2 (alio ex orbe); see, Sonnabend 1986: 202-220.

41. Schneider 1986; Schneider 1998: 104-110; Schneider 2002: 84-86, 433-436 nos. 136-138 (J. Fejfer); Landskron 2003; Landskron 2005: 57-92.

42. For the shaping of this iconography, Vos 1963; Raeck 1983: 10-66; Hall 1988; Miller 1997; Barringer 2004; Ivanchik 2005, questioning the conventional interpretation of the Athenian "Scythomania".

43. For the process of orientalising the Orient(al), see Said 1995: 49-73.

44. Schneider 1986: 39-40; Schneider 1998: 104-105.

45. Schneider 1992b; Schneider 1998: 107-109; Landskron 2005: 65-66.

46. Tran Tam Tinh 1975: 288 fig. 252; Dwyer 1982: 64-65 pl. 21 fig. 80; Schneider 1992b: 303-304 fig. 5; Pugliesi Carratelli 1997: 540-564 (Casa del Camillo, VII.12.22-27, room "e"); Schneider 1998: 107-108.

47. Tanabe 1986: 44 pl. 448.

48. Horace, carmen 1.29.7-8: puer qui ex aula capillis / ad cyathum statuetur unctis ....

49. Kempter 1980; Sichtermann 1988; Schwarzenberg 2001-02; Turnheim 2004.

50. Kempter 1980: 5; Sichtermann 1988: 154-155; Visser 1998; Schwarzenberg 200102: 166; Hertel 2003: 157, 296. - For the genealogy of Ganymede, Scheer (1997), p. 318 .

51. For the Phrygian cap, Hinz 1974: 790-792; Seiterle 1985; Schneider 1986: 19-20, 98-99, 123-124; Schneider 1998: 104; Rose 2005: 34-35.

52. Pani 1975: 74; Schneider 1986: 123; Hall 1988; Wilhelm 1988; Rose 2002a: 332; Dench 2005: 248.

53. Crawford 1974: nos. 19.2, 21.1, 22.1, 24.1, 26.4, 27.5, 41.1, 98A.3, 102.2b-c, 269.1, 288.1, 464.3b; Rose 2002a: 331-332 fig. 3. 
54. Juvenal, Saturae 6.513-516 semivir (sc. Gallus) ... plebeia et Phrygia vestitur bucca tiara. For the Galli, Graillot 1912: 287-319; Beard 1994: 164-165, 173-183; Roller 1998; Rose 2002a: 332-334. For semivir, Vergil, Aeneid 4.215, 9.614-620, 12.99: Roller 1998; 129. - For the Phrygian cap see above note 51.

55. Neudecker 1988: 46-47; Schneider 1992b. For imperial cup bearers called Ganymede, Martial, epigrammata 9.36; Cain 1993: 86-87.

56. Bremmer 1990: 141 .

57. Veblen 1899: 35-67; Bourdieu 1974: 159-201.

58. Schneider 1986: 154 n. 1166; Andreae 1994: 113-120; Andreae 1995: 115-134; Schneider 1998: 108; Schwarzenberg 2001-02: 176.

59. Andreae 1994: 113-120; Andreae 1995: 115-134; Kunze 1996: 159-223; Ulisse 1996: 68 fig. 23; Andreae 1999: 177-223; Grummond and Ridgway 2000: 111-165 (H.A. Weis), 166-190 (P. Green); Andreae 2001: pls. 98-102.

60. For the Roman iconography of Trojans in Oriental garb, Grassinger 1999: 57-63, 207-209 nos 34-40 (the release of Hector); Rose 2005: 34, 44; see also the entries, Aeneas, Alexandros, Askanios, Anchises, Hektor, Paridis Iudicium, Priamos and Troilos, in: Lexicon Iconographicum Mythologicae Classicae I-VIII, Zurich / Munich 1981-1997.

61. For the stylistic dating, Kunze 1996: 159-223.

62. The complex visual narratives at Sperlonga do not support Bernhard Andreae's monocausal interpretation of the villa as the property of the emperor Tiberius, and the sculptures as a manifesto of a supposed Tiberian ideology (see above note 59). To my mind the question of the ownership of the villa remains open: there is no justification for fixing on any particular member of the Julio-Claudian family - and the owner may just as easily have been a member of a family closely related to Augustus.

63. Bellinger 1961: 47-63 nos. T136 (Hadrian), T149 (Marcus Aurelius), T186-T187 (Commodus), T209, T211, T213 (without the image of an emperor, second century CE).

64. Zanker 1988: 201-210; Gruen 1992: 6-51; Spannagel 1999: 162-177; Erskine 2001; Mavrogiannis 2003: 15-83; Hölkeskamp 2004: 201-204; Dench 2005: 248253; Walter 2006.

65. C. Day Lewis, The Aeneid of Vergil. New York: Doubleday Anchor Books 1953: 20-21; see, Spannagel 1999: 105-107; Erskin 2001: 22-23.

66. Hardly the Trojan Achates as again supposed by Rose 2005: 44. The shepherd's crook points to Iulus/Ascanius.

67. Torelli 1999; Haselberger 2002: 189 s.v. Pax Augusta, Ara.

68. Wallace-Hadrill 2004.

69. The visible remains, however, do not clarify if Iulus/Ascanius was shown in trousers or not; contra Rose 2005: 44n. 127.

70. Zanker 1969; Kockel 1995; Rich 1998: 79-97; Spannagel 1999; La Rocca 2001; Haselberger 2002: 130-131 s.v. Forum Augusti; Ungaro 2002: 109-121; Haselberger and Humphrey 2006: 127-130, 183-190.

71. Simon 1990: 135-145; Spannagel 1999: 162-205.

72. Scholz 1970.

73. Croon 1981; Spannagel 1999: 60-78, 206-224.

74. Zanker 1969; Spannagel 1999.

75. Spannagel 1999: 365-400 (catalogue of the visual evidence).

76. Spannagel 1999: 86-161.

77. Erim 1989: 56 fig. 80; Smith 1987: 132-133 (for the location); Smith 1990: 97-98 
fig. 9; Galinsky 1992: 462-463 fig.6; Spannagel 1999: 371 no. A 17.

78. Bernoulli 1886: 277-299; Jucker 1976; Megow 1987: 202-207 no. A 85; Giard 1998; Schneider 1998: 116; Meyer 2000: 11-57; Giuliani 2004.

79. For the visual tradition of such vertical hierarchy, Schneider 1992a: 941.

80. Schneider 1997.

81. Andreae 1995a; Rose 2002a: 341-342; Giuliani 2004. For the best illustration, Giard 1998: pl. VI.

82. Weber 1972 with earlier works; Rose 2002a: 331-342 (who, on p. 339, wrongly confines the Trojan dress to "the old, the young, and the cowardly"); Rose 2005: 34. For the tensions and contradictions of Rome's cultural-ethnic origins in Roman accounts, Dench 2005: 61-69.

83. Zanker 1988: 201-210; Gruen 1992: 6-51; Spannagel 1999: 162-177; Erskine 2001; Mavrogiannis 2003: 15-83; Hölkeskamp 2004: 201-204; Dench 2005: 248-253; Walter 2006.

84. For Ilium in the early empire, Rose $2002 \mathrm{~b}$.

85. For Hector's tomb, Erskine 2001: 109; Hertel 2003: 179-180.

86. Anthologia Latina 708 (ed. Riese): Martia progenies, Hector, tellure sub ima / (Fas audire tamen si mea verba tibi) / respira, quoniam vindex tibi contigit heres, / qui patriae famam proferat usque tuae. / Ilios, en surgit rursum inclita, gens colit illam / te Marte inferior, Martis amica tamen. / Myrmidonas periisse omnes dic Hector Achilli, / Thessaliam et magnis esse sub Aeneadis. Pani (1975), pp. 74-78; Hertel (2003), pp. 280-281; Walter (2006), 89-90.

87. The avenger is Rome, as Richard Gordon orally suggested to me, not Augustus, as claimed by Hertel 2003: 281.

88. For the "cultural" clothing of the Trojans in Roman or Oriental garb as recorded by Vergil, Dench 2005: 276-277.

89. Schneider 1986; Schneider 2002: 84-88, 433-436 nos. 136-138 (J. Fejfer).

90. Schneider 1986: 166-186.

91. Cicero, Oratio de Domo Sua 60; Cicero, Oratio de Haruspicum Responsis 28. Vergil, Georgica 5.211 (populi Parthorum aut Medus Hydaspes), 5.290 (Persidis); Propertius, Carmina 3.3.11 (Medae); Horace, Carmina 1.2.22 (Persae), 1.2.51 (Medos), 1.21.15 (Persas), 1.27.5 (Medus), 1.29.4 (Medo), 1.3.1 (Persicos), 2.1.31 (Medis), 2.9.21 (Medum), 2.12.21 (Achaemenium), 2.16.6 (Medi); 3.3.44 (Medis); 3.5.4 (Persis); 3.5.9 (Medo); 3.8.19 (Medus), 3.9 .4 (Persarum), 4.14.42 (Medus), 4.15 .23 (Persae); Horace, Carmen Saeculare 54 (Medus); Horace, Epodi 13.8 (Achaemenio); Ovid, Ars Amatoria 1.225 (Persis), 1.226 (Achaemeniis); Ovid, Fasti 1.385 (Persis); Ovid, Metamorphoses 1.62 (Persidaque), 4.212 (Achaemenias); Ovid; Tristia 5.3.23 (Persidaque); see Paratore 1966; Wissemann 1981: 24-26; Sonnabend 1986: 198-199, 244-246, 280-282.

92. Schneider 1986: 58-67; Schneider 1998: 110-113; Spannagel 1999: 75-77, 206223, 226-230; Rose 2005: 45-53.

93. Res Gestae Divi Augusti 23; Schneider 1998: 112-113; Coleman 1993: 51-54; Spannagel 1999: 15; Rose 2005: 45-47. For the naval battle at Salamis, Wallinga 2005.

94. Schneider 1986: 18-97; Schäfer 1998: 67-70; Schneider 2002: 82, 84-85, 433-436 nos. 136-138 (J. Fejfer).

95. Pausanias, Periegeta, 1.18.8. For the dating of the monument in Augustan times, Schäfer 1998: 67-70; Schneider 1998: 112 with n.125. - For the Romanisation of Athens in Augustan times, Spawforth 1997; Walker 1997.

96. Schneider 1986: 50-57 pl. 9. 
97. Schneider 1986: 58; for the tripod dedicated to Delphi, Steinhart 1997.

98. Schneider 1986: 67-72; Dräger 1994: 73-96.

99. Schneider 1986: 98-125.

100. Bauer 1993; Haselberger 2002: 66 s.v. Basilica Pauli; Haselberger and Humphrey 2006: 169-173.

101. A preliminary report will be published by Tobias Bitterer, Alfons Neubauer a R. M. Schneider: "Die Orientalenstatuen der Basilica Aemilia, Ein Arbeitsbericht", in: Mitteilungen des Deutschen Archäologischen Instituts, Römische Abteilung 112 (2005).

102. Schneider 1986: 115-125; Schneider 1998: 108-110; Rose 2005: 62-63; contra Landwehr 2000: 75-76.

103. Pliny, naturalis historia 36.102 basilicam Pauli columnis et Phrygibus mirabilem (est). For this reading of the text, Schneider 1986: 120-125; Schneider 1998: 109 110.

104. Phryx as synonym for slave, Schneider 1986: 123. For the (almost) synonymous use of Phrygian and Trojan, see above n. 52.

105. Schneider 1986: 118; Kränzle 1994.

106. Vitruvius, de architectura 1.1.3 ... quod significatur et quod significant.

107. Vitruvius, de architectura 1.1.6.

108. Vitruvius, de architectura 1.1.5-6; Schneider 1986: 103-115.

109. Schneider 1986: 98-135, 200-210 SO 1-68; Castella and Flutsch 1990: 18, 24-25 fig. 9; Schneider 1998: 114-115; Landwehr 2000: 74-85 no. 110.

110. Schneider 1986: 205 SO 29-30; Schäfer 1989: 282-287 no. 22; Schneider 1998: 110.

111. Schneider 1998: 113-116.

112. For polishing, Schneider 1999: 934. For the colouring of Greek sculptures showing Orientals, Brinkmann and Wünsche 2004: 84-98, 166-173 (V. Brinkmann).

113. Östenberg 1999; Östenberg 2003; Flaig 2003: 32-40; Itgenshorst 2005; Hölkeskamp 2007: 20-28. For the spectacular staging of (acclaiming?) Parthians on top of the arch erected after $20 \mathrm{BCE}$ in the Forum Romanum to commemorate the settlement of the Parthian question, Rich 1998: 97-115; Rose 2005: 28-36.

114. For the mythical figures and political personifications, Lexicon Iconographicum Mythologicae Classicae I-VIII, Zurich / Munich, 1981-1997. - For the Galli see above note 54 .

115. Ball 2000: 7, 450 (quotations); Hingley 2005: 55-56.

116. Simon 1967: 18, 21 pls. 14, 17, 19-21; Rose 1990; Rose 2005: 38-44.

117. See above no. 35 .

118. Lately Rose 2005: $38-44$, has argued that the two boys are portrayed as foreign princes, the one on the south frieze of Oriental, the one on the north frieze of northern ethnicity, to represent the new peace that had been achieved under Augustus in both east and west.

119. Attis: Schneider 1986, pp. 133-134; Baudy 1997; Lancellotti 2002; Bremmer 2004; Landskron 2005: 59-61. - Mithras: Gordon 2000; Gordon 2001.

120. Pugliesi Carratelli 1991: 435-477, especially 464-465 figs 36a-b (Casa di Pinarius Cerialis, III.4.4).

121. Andreae 1973: pl. 105; Vermaseren 1982; Ghini 1994; Mielsch 2001: 176-177 fig. 209 (dating).

122. Gordon 2000: 288.

123. Gordon 2001. 
124. Pensabene 1982; Wiseman 1984; Wilhelm 1988; Beard 1994; Pensabene 1996; Takács 1996; Roller 1999: 261-343; Takács 1999; Bremmer 2004: 557-566; Haselberger and Humphrey 2006: 34-49.

125. Vergil, Aeneid 2.788, 6.784-785, 9.82, 10.252. Wilhelm 1988: 86.

126. Ovid, Fasti 4.272-274. Wilhelm 1988: 96.

127. Schneider 2006.

128. Hartog 1980; Hall 1989; Burkert 1992; Dihle 1994; Miller 1997; Burkert 2003.

129. Vout 2003; Bol and Kaminski and Maderna 2004: 155-274; Ägypten 2005: 331450.

130. For recent discussions on Carl Schmitt's political-theological readings of friend and foe, Meier 1994; Palaver 1998.

131. Woolf 1994.

132. Beard 1994, especially 166-167, 183-187.

133. Ball 2000: 446-450. 